\title{
Switches into and out of NREGS - A panel data analysis for Rajasthan
}

\author{
Raghbendra Jha, Raghav Gaiha, Manoj K. Pandey \& Shylashri Shankar ${ }^{1}$ \\ This version 17 January 2011
}

\begin{abstract}
India's National Rural Employment Guarantee Scheme (NREGS) has been hailed as one of the country's most creative social initiatives. Since the program was begun only recently (in 2004-05) there is a need to assess its impact on households not just in one year but over time. To the best of our knowledge there are no studies of the latter kind. Using a unique panel data set for 2007-08 and 2009-10 for the Indian state of Rajasthan this paper analyzes the transitions into and out of the National Rural Employment Guarantee. It models the impact of such transitions on earnings of workers as well the determinants of such transitions. Several policy conclusions are also advanced.
\end{abstract}

Keywords: National Rural Employment Guarantee, Panel data, labor earnings JEL Classification: C 33, H53, J68, J80, O12,

All correspondence to:

Prof. Raghbendra Jha,

Australia South Asia Research Centre,

College of Asia and the Pacific

H.C. Coombs Building (09)

Australian National University,

Canberra, ACT 0200, Australia

Phone: + 6126125 2683; Fax: + 6126125 0443; Email: r.jha@anu.edu.au

\footnotetext{
${ }^{1}$ Jha: Australia South Asia Research Centre, College of Asia \& the Pacific, Australian National University, Canberra, Australia (email: r.jha@anu.edu.au). Gaiha: Faculty of Management Studies, University of Delhi, Delhi, India. Pandey: Australia South Asia Research Centre, College of Asia \& the Pacific, Australian National University, Canberra, Australia (email: manojkp23@gmail.com). Shankar: Centre for Policy Research, New Delhi (email: shylashris@gmail.com). We gratefully acknowledge financial support from Australian Research Council-AusAID Linkage grant LP0775444 and thank Raj Bhatia for expert statistical assistance. The usual caveat applies.
} 


\section{Introduction}

There is high incidence of both open unemployment and poverty in rural India. According to the $61^{\text {st }}$ Round Household data from the National Sample Survey 8.3 percent of male workers and 7.5 percent of female workers were unemployed in rural India in 2004-05. This fact, along with a high incidence of poverty in rural India (28.7 percent in 2004-05) indicates the high relevance of using a well designed workfare program to address the twin problems of high poverty and high unemployment in the rural sector.

When the National Rural Employment Guarantee Act came into effect in November, 2005 it was hailed as one of India's most creative social initiatives. The act guarantees 100 days of employment a year to at least one member of any rural household who is willing to perform unskilled labor for the minimum wage. By combining rural development with livelihood protection, the work is designed to develop infrastructure such as roads, irrigation and flood protection measures. Beginning with the poorest 200 districts, NREGA became a nationwide program in April, 2008.

During its first year of operation National Rural Employment Guarantee Scheme (NREGS) involved an expenditure of $\$ 4.5$ billion and was expected to generate 2 billion days of employment. NREGS's performance is also crucial to the success of the Millennium Development Goal of halving global poverty by 2015. NREGS has recently been extended to cover all districts of India. In the budget of 2010-11 expense earmarked for NREG was Rs. 401 billion ( $>\$ 8$ billion).

Against this backdrop it is important to ask both how much benefits have accrued from this program to eligible workers and whether these benefits have persisted over time. The first issue can be addressed using household level cross section data and some dimensions have been addressed in a series of papers (Jha et al. 2010 a, for employment and Jha et al. 2010 b, for nutritional impact). The second issue can only be addressed using household level panel data to track the movement of workers in and out of employment in the NREGS.

This paper uses a unique data set for two years, 2007-08 and 2009-10, for the state of Rajasthan in India to address this question. The plan of this paper is as follows. In section II we discuss the sources of data, section III constructs the results of 2007-8 with those for 2009-10 and describes the movement of workers in and out of NREGS. Section IV models the determinants of such transitions; section $\mathrm{V}$ analyzes the dynamics of participation and exit from the NREGS. Section VI concludes.

\section{Data}

The present analysis is based on primary household level panel survey data from Rajasthan for years 2007-08 and 2009-10. The modus operandi for collecting the data from household survey in the year 2007-08 was as follows. A list of Rajasthan NREGS districts ${ }^{2}$ was

\footnotetext{
${ }^{2}$ Please note that NREGS was implemented only in 7 districts of Rajasthan in 2007-08. Subsequently, coverage of districts under NREGS increased in the state.
} 
compiled. From these districts, three were selected on the basis of probability proportional to size (in this case, rural population as reported in the 2001 Census). In the next stage, a total of twenty five villages were randomly chosen from districts selected in the previous stage. Finally, from each selected village, twenty households were again randomly selected giving us a sample of 500 households in Rajasthan. In 2009-10 also, a total of 500 households were sampled. However, only 476 households were panel (those are common in both the years). The remaining 24 households were different. One of the reasons for those missing households is that some NREGS villages in 2007-08 were no longer NREGS villages in 2009-10.

Thus, our analysis is based on a panel of 476 households. It is to be noted that the same set of villages, household and individual level questionnaires were canvassed again in 2009-10 as in the year 2007-08. Apart from household level information, individuals within the households were also interviewed. The data include information on personal attributes of household's head, social group, occupation, landholdings, income and expenditure, household size, NREG participation $^{3}$, type of ration card, PDS participation along with other village and individual level information. ${ }^{4}$

Apart from these questionnaire based information, detailed ethnographic interviews were conducted in 2008-9 in the period between the first and second surveys. About 20-25 respondents belonging to a cross -section of villagers and block level officials/political leaders were interviewed in a subset of eight villages selected according to the political affiliation of the village president (sarpanch). Since the sarpanch is elected along nonpolitical party lines, we found his/her political affiliation during the larger household survey. Fifty percent of the villages had sarpanches affiliated to one party, and the other half were affiliated to the opposing party. Two trained interviewers in each state team who spoke the local language and were cognizant of the requirements of ethnographic research conducted the interviews. The interviews contain anecdotes and examples of corruption, the decision making process of the panchayat (village governing body), the process of choosing NREG projects, the influence of political parties on village level issues, the migration rates and agricultural wages in the village, the impact of caste and income on the ability to influence decisions, the information available to the respondent about the NREG, and awareness of social audit, right to information, among others. ${ }^{5}$ We also conducted focus group sessions in 25 worksites per state. These ethnographic interviews provide us with the perceptions of the beneficiaries, policymakers and village level elites on the dynamics of power and the impact of the NREG.

\footnotetext{
${ }^{3}$ A household is said to be a NREG participating household if at least one of its individual member has worked for some time under NREGS in the last 365 days.

${ }^{4}$ A household is said to be PDS participating household if it has draws foodgrain (rice or wheat) or sugar or kerosene from PDS

${ }^{5}$ The interviewees included the village sarpanch, ex-sarpanch, deputy sarpanch, gram sevak, NREG assistant, caste leaders, panchayat members, village development committee members, political activists from the leading parties, NGOs in the village, the Patwari, moneylender, ration shop owner, worksite supervisor, NREG beneficiaries at the worksite, and individual asset creation beneficiaries. At the block level, we interviewed the Block Development Officer, the NREG program officer, the junior engineers, ward panchayat members, and the Pradhan. We also interviewed the member of the Legislative Assembly (MLA).
} 


\section{Results}

\section{Contrast between 2007-08 and 2009-10}

Table 1 shows changes in the distribution of households over the two time periods 2007-08 and 2009-10.

\section{Table 1 here.}

The following points about the transition from 2007-08 to 2009-10 are notable. As expected, there was no significant change in the gender composition of the household heads. Households headed by males remained in vast majority (more than 95 percent) in 2007-08 as well as 2009-10. There was no significant change in the social status of households either. Household size increased slightly from 2007-08 to 2009-10 for all households except for those with 4-8 family members. However, this change is not statistically significant.

We next examine how economic conditions of panel households changed between 2007-08 and 2009-10. To measure economic status, we use different poverty categories based on per capita monthly expenditure (defined in annex Table A.1) as well as land ownerships. The results are depicted in Table 2.

\section{Table 2 here.}

The top panel of Table 2 documents how the distribution of households changed by their poverty status during 2007-08 and 2009-10. Based on their per capita monthly consumption expenditure (PCME), while about 40 percent households were below the poverty line in 2007-08 the proportion of poor households increased by about 18 percentage points in 200910. More significantly, much of the increase in the proportion of poor households was because of an increase in acutely poor households. In such households, percentage of poor increased from 29 percent in 2007-08 to about 43 percent in 2009-10. In contrast, the proportion of affluent households decreased by more than 16 percentage points during the same period. Change in poverty status is validated by Chi-square test at 1 percent level of significance.

We next investigate the distributional shift in the poverty status of those households. The second panel of Table 2 reports that about 70 percent of the acutely poor households in 200708 remained acutely poor in 2009-10 too. The remaining 30 percent became better-off over time. Among households that were moderately poor in 2007-08, only 18 percent retained their status. About 64 percent of them became acutely poor in 2009-10 and the remaining 18 percent became non-poor.

Among households that were moderately non-poor in 2007-08, less than 27 percent remained so in 2009-10 and about 23 percent became affluent. However, nearly half of them became poor (out of which 36 percent became acutely poor and 15 percent became moderately poor). Only 43 percent of those households who were affluent in 2007-08 remained so in 2009-10; 19.51 percent of such households moved to the moderately non-poor category, while nearly 20 percent and 17 percent of them, respectively, were acutely and moderately poor in 200910. About 41 percent of the non-poor households in 2007-08 became poor in 2009-10, and 
about 17 percent of the poor households in 2007-08 became non-poor in 2009-10. Thus there was a significant change in the poverty status of panel households between 2007-08 and 2009-10. This result is validated by Pearson's Chi-square test at the 1 percent level of significance.

The third and fourth panels of Table 2 report changes in the percentage distribution of households and mobility of those households by land holding between 2007-08 and 2009-10, respectively. The proportion of landless households fell from 31.35 percent to 29.69 percent. Similarly, the share of those with land holdings between $0-1$ acres and between 1-2 acres also decreased in this period (greater reduction occurred in the former category of households). Interestingly, the proportion of households with land holding $>2-\leq 5$ acres increased dramatically from just 12 percent in 2007-08 to more than 31 percent in 2009-10. A similar pattern also emerged for households in the largest land owning group ( $>5$ acres). Their proportion rose by 8 percentage points in 2009-10. Pearson Chi-square statistics with 4 degrees of freedom suggests that land holding is time variant. Among households that were landless in 2007-08, more than 26 percent moved out of the landless category (11 percent held $>2$ acres in 2009-10). Among households with land holdings of between 0-1 acre in 2007-08, 9.69 percent remained in the same category whereas 16.16 percent were landless in 2009-10. Land holdings increased among the remaining households. Similarly, among households with land holdings between 1-2 acres in 2007-08, 11 percent experienced a reduction in their land ownership (5 percent become landless and 6 percent had 0-1 acre) in 2009-10. Among those households with 2-5 acres land in 2007-08, 7 percent became landless, 22 percent were in the group owning 1-2 acres, 37 percent remained unchanged and the remaining 34 percent shifted into the highest land owned category (i.e. $>5$ acres) in 200910. Finally, among those households with more than 5 acres of land in 2007-08, only 46 percent remained in the same land ownership category in 2009-10. Thus, overall, there were significant changes (shift) in land holdings movements of panel households during 2007-08 and 2009-10- the result is validated by Pearson's Chi-square test at the 1 percent level of significance.

\section{Table 3 here.}

In Table 3 we detail changes in the participation of households in NREGS. Overall, proportion of NREGS participating households decreased from 68 percent in 2007-08 to 48 percent in 2009-10. The participation of female households did not increase significantly with their participation corresponding to their proportion in the population. While participation of Scheduled Castes (SCs) and Others in NREGS increased slightly between 2007-08 and 200910, the proportion of Scheduled Tribes (STs) and Other Backward Castes (OBCs) participants dropped. However, this change is not statistically significant for any of the groups. Over this period the proportion of households with family size less than 5 and more than 8 rose and the proportion of households with family size 5-8 fell. This variation was, however, statistically insignificant. Between 2007-08 and 2009-10, participation in NREGS by acutely (moderately) poor increased by 22 (2) percent. Hence, participation by poor in general increased. The proportions of moderately non-poor and affluent (and hence, of nonpoor households) decreased by 0.26 and 24 percentage points, respectively. Participation in 
NREGS by landless households and those households with holdings of between 0-1 acre and 1-2 acres decreased by 5,20 and 10 percentage points, respectively. However, the opposite is true in the case of those with more than 2 acres of land. Their participation in NREGS rose sharply. The Pearson Chi-square statistics suggest that participation in NREGS by households with various economic status (based both on PCME as well as land holdings) changed significantly between 2007-08 and 2009-10.

\section{Analyzing Switches into and out of NREGS}

To analyze switches into and out of NREGS, based on 476 panel households for 2007-8 and 2009-10 we classify households into four categories:

I. Those who participated neither in 2007-08 nor in 2009-10;

II. Those who participated in 2007-08 but withdrew in 2009-10;

III. Those who did not participate in 2007-08 but participated for the first time in 2009-10 and;

IV. Those who participated in 2007-08 and continued participation in 2009-10.

Based on this classification, we define four types of households: Type I, Type II, Type III and Type IV households. The percentage distribution of these households is shown in Figure 1.

\section{Figure 1 here.}

Figure 1 suggests that 30 percent of households never participated in NREGS. 23 percent households withdrew in 2009-10 after participating in 2007-08. Only slightly less than 3 percent of the households entered in the scheme for the first time in 2009-10. 45 percent of the households continued their participation.

Table 4 depicts distribution of four types of households by these characteristics in the base year (2007-08).

\section{Table 4 here.}

Both row and column percentages are reported. However, we comment only on row percentages. Key observations are as follows:

In both female and male headed households, the proportion of Type IV households is the highest. However, while the proportion of Type II households is the second highest among former, Type I households comes second in the latter. While Type IV households are in majority among SCs, STs and OBCs households, among 'others' social group the proportion of Type I is the highest. Going by poverty status of the households in 2007-08 and 2009-10, we observe that while among acutely poor, moderately poor (hence, among all poor) and moderately non-poor households, the proportion of Type IV households is the highest, among affluent and non-poor at large, proportion of Type I households is the highest. The majority of the landless households are Type I households. Among households with land holdings $>0$ $\leq 5$ acres, the proportion of Type IV households is the highest. However, majority of those with land holding $>5$ acres in 2007-08 were Type I households. 
We then investigated whether households who moved out of the NREGS are better off. To determine this, we see how distribution of CPIAL adjusted income net of NREGS and PCME change over this period. This is documented in Table 5.

\section{Table 5 here.}

Table 5 documents mean, median, standard deviations of PCME and per capita monthly income net of NREGS earnings (PCMINNE) for all four types of households for years 200708 and 2009-10. We also test whether changes between 2007-08 and 2009-10 are statistically significant. Significance of differences in paired means is tested using t-test (a parametric test). Further, non-parametric tests: Wilcoxon signed-rank test ${ }^{6}$ and sign tests ${ }^{7}$ were used to test whether distribution of these variables is same (i.e., median is equal) over time.

Results are also supplemented by Stochastic Dominance test (Atkinson, 1987). ${ }^{8}$ In this test, cumulative distribution functions (CDFs) of PCME/PCMINNE separately for two years are plotted for all the four type of households. If the cumulative income distributions functions for year 2007-08 lies above that of year 2009-10 over the complete range of poverty thresholds, the first-order dominance (FOD) holds. This implies that the targeting of the former is better in terms of a class of poverty indices comprising the head-count ratio, the poverty gap and a distributionally sensitive measure over the complete range of poverty thresholds (the Rawlsian maximin principle is a special case). If, however, the two curves intersect, a second-order dominance test is used that permits such comparisons for all such indices except the head-count index, and so on.

Our key conclusions are as follows. Both PCME and PCMINNE fell significantly over the period 2007-08 to 2009-10 for all four types of households. This is validated by means of statistical tests such as t-tests, signed rank tests and sign test (Table 5). Stochastic dominance test confirms first order dominance implying that PCME in 2009-10 for each of the four types of households are dominated by respective magnitudes for 2007-08, i.e., PCME fell between 2007-08 and 2009-10 (Figures 2-5) for all four categories of households. A similar result holds in case of per capita income net of NREGS wage earnings for all types of households (Figures 6-9).

\section{Figures 2 to 9 here.}

To measure changes in the per capita income over time, we construct two variables as follows: We define percentage increase in MPCE by subtracting its value for base year (2007-08) from the current year (2009-10) multiplied by 100 and then dividing by base year's value. Similarly, percentage increase in per capita income net of NREGS wage earnings over time by subtracting its value for base year (2007-08) from the current year (2009-10) multiplied by 100 and then dividing by base year's value. Then, we examine whether the

\footnotetext{
${ }^{6}$ It tests the equality of matched pairs of observations by using the Wilcoxon matched-pairs signed-ranks test (Wilcoxon 1945). The null hypothesis under Wilcoxon signed-rank test is that distributions for both the years 2007-08 and 2009-10 are the same.

${ }^{7}$ It tests the equality of matched pairs of observations. The null hypothesis is that the median of the differences is zero.

${ }^{8}$ The test enables ordinal poverty comparisons for a range of poverty thresholds and a class of poverty indices.
} 
households which never participated in NREGS have higher changes in the MPCE and per capita income net of NREGS wage earnings over time than those who withdrew in 2009-10, those who entered first time in 2009-10 and those who continued participation in 2009-10. To do this we rely on ordinary least squares (OLS) regression with robust standard errors. ${ }^{9}$ Controlling variables other than dummy for types of household (Type I being the reference group) are dummies for social group of household (SC, ST, OBC vs. Others), household size for both base year and change in it (household size in 2009-10 minus household size in 200708) and initial year's per capita income. These models are validated by F-test at the 1 percent level of significance.

Table 6 reports estimates for percentage change in both MPCE and PCMINNE over 2007-08 and 2009.

\section{Table 6 here.}

We find that there is no significant difference in the percentage change in MPCE or PCMINNE for Type I and Type II households. This suggests that there isn't a significant increase in the income with respect to the initial year's income in those households which participated in 2007-08 but withdrew in 2009-10 and those who participated neither in 200708 nor in 2009-10. However, as compared to those households who never participated, percentage change (increase) in MPCE or PCMINNE is significantly lower for those who either entered first time in NREGS or who continued their participation. This indicates that households with lower change in income are more likely to join the scheme or continue their participation if already in the program. As expected, the higher the base year's per capita income, the lower is the percentage change with respect to the base year's per capita income. However, other control variables are insignificant.

We then investigated whether changes in the share of per capita income from agricultural and non-agricultural sources (net of NREGS earnings) lured or kept households from participation in NREGS. For this, we summarize some of the descriptive statistics (such as mean, standard deviation and median) for share of per capita income from agricultural sources (agriculture, live-stocks and agricultural wages) in total per capita income for base year 2007-08 and percentage change in the period 2007-08 to 2009-10. We also summarize these descriptive statistics for share of per capita income from non-agricultural sources (nonagriculture wages, salary, self-employed business trade/artisans/professionals, and others such as pensions, remittances, rent, interest and dividends) in total per capita income for base year 2007-08 and percentage change in this between 2007-08 and 2009-10 with respect to

\footnotetext{
${ }^{9}$ Another way to deal with this problem is to use Analysis of Variance (ANOVA) analysis. However, an essential assumption of ANOVA is the equality of variances of the dependent variable across the types of household. When this assumption is violated, the reported p-value from the significance test may be too liberal (yielding a higher than expected type I error) or too conservative (yielding a lower than expected type I error). In our analysis, Bartlett's test for equal variances suggests that variances are significantly unequal (results are not reported here but can be obtained from the corresponding author upon request). As a remedy of violation of this assumption, $\mathrm{W}$ and $\mathrm{F}^{*}$ robust one way ANOVA is performed. Both w-test and $\mathrm{F}^{*}$ are more robust to violations of homogeneity of variances than tradition F-test. However, commands for these tests in STATA do not permit any types of sampling weights and therefore, we rely on OLS regression with robust standard errors.
} 
base year. A positive value of these changes indicates increases and negative changes reductions in the share over time. Table 7 reports descriptive statistics and pair-wise comparisons of means for these shares and percentage changes in these.

\section{Table 7 here.}

Now, to examine significance of differences of means pair-wise among four types of households in these shares as well as percentage changes in them, we employ Bonferroni multiple-mean comparison test used along with one-way ANOVA. Table 8 depicts t-statistics for the multiple comparison tests for the means of shares and their changes from both agricultural and non-agricultural sources.

\section{Table 8 here.}

Our key conclusions are as follows. In the base year (2007-08) the mean share of per capita annual income from agricultural sources in total per capita income for all other households as compared to the households who never participated, were significantly higher. Further, as compared to the households who participated in 2007-08 but withdrew in 2009-10, mean share of per capita annual income from agricultural sources in total per capita income for those who participated first time in 2009-10 and continued participation in 2009-10 were significantly higher. However, mean share of per capita annual income from agricultural sources in total per capita income is higher for those who continued participation in 2009-10 as compared to first time participating households.

As far as mean percentage change (increase) in the household's share of per capita income from agricultural sources is concerned, as compared to never participating households, it is significantly higher for those who ceased participating, but significantly lower for those who participated for the first time in 2009-10 and those who continued participation. Further, as compared to those households who withdrew, there were significantly lower mean percentage changes (increase) in the household's share of per capita income from agricultural sources for those who enter first time and for those who continued participation in NREGS. Between those who participated for the first time and those who continued participation, mean percentage change (increase) in the household's share of per capita income from agricultural sources is significantly higher for latter.

In the base year (2007-08) as compared to the households who never participated, mean share of per capita annual income from non-agricultural sources net of NREGS earnings in total per capita income for all other households were significantly lower. Further, as compared to the households who participated in 2007-08 but withdrew in 2009-10, mean share of per capita annual income from non-agricultural sources net of NREGS earnings in total per capita income for those who participated first time in 2009-10 and continued participation in 200910 were significantly lower. Also, mean share of per capita annual income from nonagricultural sources net of NREGS earnings in total per capita income is lower for those who continued participation in 2009-10 as compared to first time participating households. 
As far as mean percentage change (increase) in the household's share of per capita income from non-agricultural sources net of NREGS earnings is concerned, as compared to never participating households, it is significantly higher for those who withdrew and those who continued their participation but significantly lower for those who participated first time in 2009-10. Further, as compared to those households who withdrew, there were significantly lower mean percentage change (increase) in the household's share of per capita income from non-agricultural sources net of NREGS earnings for those who enter first time and for those who continued participation in NREGS. Between those who participated for the first time and those who continued participation, mean percentage change (increase) in the household's share of per capita income from non-agricultural sources net of NREGS earnings is significantly higher for latter.

Thus, our results strongly suggests that there is a significant reduction in the share of per capita income from both agricultural as well as non-agricultural sources net of NREGS wages among those households who participated either for the first time in NREGS or those households who continued their participation, as compared to those who never participated or withdrew after initial participation. Also, mean shares of per capita income from both sources (those who never participated and those who withdrew after initial year's participation) significantly increased from 2007-08 to 2009-10.

\section{Determinants of Switches into and out of NREGS}

\section{The Model}

We constructed an estimation equation for the four types of households. As defined above, it is a multiple response categorical dependent variable that takes the value 1 if household is of Type I, 2 if household is of Type II, 3 if household is of Type III and 4 if household is of Type IV. This provides definitive insights into the household and village level characteristics that determine the likelihood of these households' types. Some of the explanatory variables that were included in the model to test their effects are (i) characteristics of households such as social group (SC, ST, OBC vs Others), proportion of adults, and land holdings; and (ii) village level characteristics such as ratio of NREGS to agriculture wage rate, average distance of NREGS sites, and per capita annual earnings from non-agricultural sources net of NREGS earnings (as a proxy for employment opportunities in the village other than NREGS). For time variant household and village level variables, both initial (base) as well as change in the variables over time under study are used. Average distance of NREGS sites from the village is an exception, where only base variable is used due to very small changes during 2007-08 and 2009-10. Definitions of these variables are given in annex Table A.2.

The model for household type $j$ is

$$
P\left[Y_{i}=j\right]=\frac{e^{\beta^{\prime}{ }_{j} x_{i}}}{\sum_{k=1}^{4} e^{\beta_{k}^{\prime} x_{i}}}, j=1,2,3,4 .
$$

Where $j=1,2,3,4$ refers to type of household. This model is called multinomial logit model (Greene, 2003). The estimated equations yield a set of probabilities for $j+1$ choices for a 
decision maker with characteristics $x_{i}$. Following Greene (2003), out of four choices, only three parameters vectors are needed to determine all the four probabilities. The probabilities are given by

$$
P\left[Y_{i}=j / x_{i}\right]=\frac{e^{\beta^{\prime} x_{i}}}{1+\sum_{k=1}^{J} e^{\beta^{\prime} x_{i}}}, \text { for } \quad j=1, \ldots . . J, \beta_{0}=0
$$

For our purpose, we use $j=4$ as obvious omitted or reference group. Further, $\beta$ coefficients in this model are difficult to interpret (Greene, 2003) and therefore, we compute marginal effect corresponding to each $j=1,2,3$ as

$$
\delta_{j}=\frac{\partial P\left[Y_{i}=j\right]}{\partial x_{i}}=P\left[Y_{i}=j\right]\left[\beta_{j}-\bar{\beta}\right] ; j=1,2,3,4 \text {. }
$$

Thus every sub-vector of $\beta$ enters every marginal effect, both through the probabilities and through the weighted average that appears in $\delta_{j}$. These values can be computed from the parameter estimates and standard errors are computed using the delta method.

\section{Econometric Results}

The estimation results are given in Tables 9 and 10. Table 9 contains coefficient estimates. Note that the base (reference or omitted) case is Type I households, leaving Type II, III and IV households for detailed analysis. The model specification is validated by Wald chi-square statistics at 1 percent level of significance. Table 10 reports their corresponding marginal effects. As the latter are more meaningful, we shall confine our comments to the latter.

\section{(1) Type I households}

As compared to others, the probability of never participating is significantly lower in SCs, STs and OBCs households. Higher land ownership in the base year increases the likelihood of never participating in NREGS. However, increase in land holding over time does not have a significant effect. Ratio of village level NREG to agricultural wage rates in the initial year reduces the probability of never participation in NREGS. However, increase in the ratio does not have a significant effect on it. Increase in the village level per capita annual earnings from non-agricultural sources net of NREGS earnings in the base year increases the probability of never participation under NREGS. However, percentage change in village level per capita annual earnings from non-agricultural sources net of NREGS earnings in current year relative to the base year does not have a significant effect on the likelihood of never participation. Effects of household composition in terms of share of adults (both initial percentages and change) and village distance from the NREGS work sites in 2007-08 are not statistically significant.

\section{(2) Type II households}

The likelihood of a household to withdraw from NREGS is significantly higher if they are from SCs, STs and OBCs social groups as compared to others. This means that as compared to others SCs, STs and OBCs are more likely to withdraw from NREGS participation after participating in 2007-08. Household composition in terms of proportion of adults and land ownership of households (both initial and change) do not have a significant effect on the probability of moving out from NREGS participation after participating initially. Higher 
initial year's ratio of NREG to agricultural wage rates in a village increases the likelihood of its households to withdraw from NREGS participation in the current year. However, change (increase) in the ratio does not have a significant effect. Increase in the village level per capita annual earnings from non-agricultural sources net of NREGS earnings in the base year also increases the likelihood of the households to withdraw from the NREGS after participating in initial years. However, percentage change in village level per capita annual earnings from non-agricultural sources net of NREGS earnings in current year relative to the base year does not have a significant effect on the probability of existence of Type II households. Initial year's village distance from the NREGS work sites is not statistically significant.

\section{(3) Type III households}

There is no significant difference in the likelihood of newly entered participating households (Type III households) among SCs, STs and OBCs as compared to 'others' social group. Also, household composition in terms of proportion of adults both initially and subsequent change does not increase or decrease the probability of first time entrance in NREGS. Increase in the household's land ownership in the base year (but not increase over time); increases the likelihood of a household to participate first time in the scheme.

Though initial year's ratio of village level NREG to agricultural wage rates does not alter likelihood of a household to participate first time in the scheme significantly; increase in its value over time has significant and positive effect on the probability of a household to participate first time in the scheme. Similarly, initial year's village level per capita annual earnings from non-agricultural sources net of NREGS earnings do not increase the likelihood of a household to participate first time in the scheme significantly. However, percentage change in village level per capita annual earnings from non-agricultural sources net of NREGS earnings in current year relative to the base year increases the likelihood of Type III households significantly. Initial year's village distance from the NREGS work sites is not statistically significant.

\section{(4) Type IV households}

As compared to 'others' social group, the probability of a household of continuing in the NREGS does not vary significantly for SCs, STs and OBCs. Also, increase in the proportion of adults in the household in initial year as well as increase over time does not have a significant effect on the likelihood of Type IV households. In contrast to those who participated for the first time in 2009-10, likelihood of a household continuing under scheme decreases significantly with increases in its initial year's land ownership. However, change in the land holdings over time does not change the likelihood of Type IV households.

Neither initial year's ratio of village level NREG to agricultural wage rates nor increase in its value over time have significant effects on the probability of household's continued participation. The higher the village level per capita annual earnings from non-agricultural sources net of NREGS earnings in the base year, lower is the probability of continued participation in NREGS. However, the percentage change in village level per capita annual earnings from non-agricultural sources net of NREGS earnings in current year relative to the base year does not have a significant effect on the likelihood of households to continue their 
participation in the scheme. Initial year's village distance from the NREGS work sites is not statistically significant.

In sum, the role of incentives in participation in NREGS is confirmed. Workers exit from NREGS when they see better economic opportunities elsewhere in the village economy while others enter the scheme because of the lure of remunerative wages.

\section{Explaining the dynamics of participation and exit from the NREG}

The ethnographic study conducted in the period between the first study and the panel study illuminates some of the perceived dynamics triggered by the NREG. The patterns that emerge from these interviews are consistent with the above analysis. This explains why those belonging to the type II households exited NREG in 2010. Exits could have occurred due to several reasons:

a) Workers found more lucrative work as agricultural laborers. For instance, in Dharkada village, the worksite beneficiaries (women) said that the agricultural wages had increased from Rs 20-30 per day to Rs 60-70. The village president (Sarpanch) gave a higher figure (previously Rs 60-70 and now Rs 100). But both agreed that wages in the agricultural sector had increased as a result of NREG (to keep pace with the NREG wages). The perception in the villages is that NREG, whose wage rates are pegged to the statutory minimum agricultural wages, has been instrumental in increasing agricultural wages. In Gurari village, the supervisor on the worksite said that the wages for unskilled and skilled workers had increased to Rs 100 and Rs 125, respectively, and this was corroborated by the beneficiaries (who were interviewed separately), village elites (sarpanch, patwari, female panchayat representative ,among others) and government officals (development officer, Dharkada, Block Development Officer). A female panchayat samiti member in Dhundiya said that the wages of other jobs in the village too had increased by about $25 \%$ due to the NREG. In several villages the refrain was that workers were not willing to come and work on the site for several reasons including their ability to earn higher wages in farming and non-farm sector and their reluctance to engage in strenuous manual activity in the peak of summer.

b) They worked on their own expanded land holdings. Our panel data (Table 4) shows that $30 \%$ of Type II households owned $>1-<2$ acres of land in $2007-8$, and about $56 \%$ owned $>2$ acres, but in 2010, only 1\% owned $>1-<2$ acres and over $70 \%$ owned more than 2 acres. These figures indicate that these households increased their ownership of land. However, since the numbers of acutely and moderately poor among these households also increased (though not as dramatically as for the Type III households), it is clear that ownership of land (especially if it is non-arable land) alone cannot lift a household out of poverty. Perhaps the explanation is as follows: In Rajasthan, the worksites functioned all year round, and not just in lean seasons. If the worksite was functional during the agricultural season, these Type II households (who had increased their landholdings) may have exited since they needed to work on their own lands and also needed to pay the hired workers. In the qualitative survey, several farmers complained that they were unable to get labor during the harvest season because of ongoing NREG work, and that the agricultural wages had gone up. For instance, the Deputy Sarpanch of Dharkada said that wage increases due to NREGS had fuelled labor shortages in other jobs. In order to pay for labor during harvests, these type II households 
could have augmented their income through non-farm jobs in construction sites and other work in nearby towns.

c) Worked in non-farm jobs: The Type I and Type II households were more likely to live closer to markets (which we take as a proxy for a town) than the other two types of households. If we take the distance to the market as a proxy for distance to the nearest town, the figures show that for all three types of households, the distances to the nearest market have decreased. For instance, the distnace as $12.31 \mathrm{~km}$ in 2008 and is now $10.45 \mathrm{~km}$ for Type III households, while it was $10.15 \mathrm{~km}$ in 2008 and is now $9.28 \mathrm{~km}$ for Type 2 households. Type I and Type II households are closer to the nearest market $(7.24$ and $9.28 \mathrm{~km}$ respectively) than Type III and Type IV households (10.45 and 10.70km respectively).

With the boom in the construction industry in the state since 2008, the opportunities for skilled and unskilled laborers increased and were more lucrative than working on the NREG. Type III households, on the other hand, were more likely to live further away from the market, had less connectivity, and less access to such jobs. These perceptions need to be examined more systematically.

Among Type IV households, the reasons for continuing to stay within the program can be traced to their use of NREGS as an additional source of income. A typical story of a Type IV household is as follows: One scheduled tribe beneficiary in Dharkada village said that he had 6 - 7 Bigha land on which he sowed corn during the monsoons. For rest of the year, his land was fallow as there was no water available for irrigation. His two sons were sitting idle at home, and earned intermittently through manual labour to meet household expenses. The entire family lived in a thatched (kutcha) house. "Under this (NREGS) scheme, the Panchayat selected us and got us a job card, and my sons got work. As an individual beneficiary, a new well was constructed. ${ }^{10}$ This will enable me to grow more crops as water has become available from the well. Today, the condition of my house is better. Under this scheme, employment is available within the village, and day-to-day expenses are met. Now we sow foodgrains in our land, and eatable grains are produced there. We don't have to go out to earn as work is available in the village for the poor people. Because of this, condition of poor people like us has improved. As a result, we want Government should always continue this scheme, so that poor illiterate persons can maintain their families from wages earned from the scheme." This story seems to be that of a type IV household that has seen a marginal improvement in its circumstances from the NREG. The figures from the website of the Rajasthan government on the NREG indicate an increase in individual beneficiary schemes. About 113468 projects were taken up in 2008-9 for land development and provided irrigation facilities to those who owned land and qualified as individual beneficiaries and increased to 156468 projects in $2010-11 .^{11}$

\footnotetext{
${ }^{10}$ The government increased its emphasis on the individual beneficiary scheme from 2008. Under this scheme, a part of the NREG funds were set aside to develop productive assets on the lands of individual beneficiaries. 'We want to make the poor people more self sufficient through this scheme by creating productive assets on their lands,' said one senior officer in Udaipur.The NREG funds provided irrigation facilities on lands owned by SC, ST, BPL and beneficiaries of land reforms and Indira Awaas Yojana.

${ }^{11}$ http://164.100.12.7/Netnrega/mpr_ht/nregampr_dmu.aspx?state_code=27\&flag=21\&page1=D\&month =Latest\&fin_year=2008-2009 (Accessed $12^{\text {th }}$ January 2011).
} 
Another perception of the interviewees in several villages was that migration had reduced since 2007-8. 'Earlier members of my family used to go to Jaipur for work, but now they don't go anymore because of NREG,' said one worksite beneficiary from Dhundiya village. Similar sentiments were expressed by government officials, political leaders and village elites. Previously, before the NREG, the villagers (including boys and girls from the age of 14) used to go to the cities or work on farms to earn a livelihood, said the worksite interviewees in Dharkada (all women and belonging to a scheduled tribe). However, in Kota (an ST village), the former sarpanch said that migration continued and had not reduced while the sarpanch said that it had reduced. The BDO explained that men from this and other villages went to Udaipur to work while the women stayed back and worked in the NREG. If we combine this with our panel data in Table 4 which reveals that almost 50\% of Type III households belonged to Scheduled Tribes, and were first time entrants into the NREG, the story that emerges is one where females were sent to NREG worksites while males went to find better paying jobs in the city. However, since all these are based on perceptions, we need to assess whether the migration has actually reduced, and if so, is it because people prefer to work in NREG projects or is it because there has been an expansion of lucrative non-NREG (farm and non-farm jobs) in the villages.

What is clear from the ethnographic survey is that the general perception is that the NREG has increased wage rates in other jobs (farm and non-farm).

\section{Conclusions}

Using household level panel data for the Indian state of Rajasthan this paper has considered the important issue of how the benefits in terms of employment and earnings from a workfare program vary over time. It has described movements in and out of the NREGS for various groups of households in the sample as well as the impact such transitions have on earnings. We also model the determinants of such transitions; and the dynamics of participation and exit from the NREGS. Hence, this paper provides the first systematic analysis of the dynamics of entry, participation in and exits from the NREGS. Several policy conclusions follow from our analysis.

\section{References}

Atkinson, A.B. (1987) “On the Measurement of Poverty”, Econometrica, 55, 749-64.

Greene, W.H (2003). Econometric Analysis. $5^{\text {th }}$ Edition, Delhi, Pearson Education, India.

Jha, R. Gaiha, R., Shankar, S. and M. Pandey (2010 a) "Targeting Accuracy of the NREG: Evidence from Madhya Pradesh and Tamilnadu”. ASARC Working Paper 2010/19, Australian National University, Canberra

Jha, R. Bhattacharyya, B. and R. Gaiha (2010 b) “Social Safety Nets and Nutrient Deprivation: An Analysis of the National Rural Employment Guarantee Program and the Public Distribution System in India” forthcoming, Journal of Asian Economics.

Wilcoxon, F. (1945). Individual comparisons by ranking methods. Biometrics, 1, 80-83. 
Table 1: Changes in the Percentage Distribution of Household's Composition in Rural Rajasthan: 2007-08 to 2009-10

\begin{tabular}{|c|c|c|c|c|}
\hline Household Composition & $2007-08$ & $2009-10$ & Changes & Pearson Chi-square \\
\hline \multicolumn{5}{|c|}{ Gender of Household Heads } \\
\hline Female & 4.14 & 4.37 & +0.23 & \multirow{2}{*}{$\begin{array}{l}\text { Pearson chi2(1) } \\
=0.0356\end{array}$} \\
\hline Male & 95.86 & 95.63 & -0.23 & \\
\hline \multicolumn{5}{|l|}{ Social Group } \\
\hline SC & 25.58 & 25.58 & 0.00 & \multirow{4}{*}{$\begin{array}{l}\text { Pearson chi2(3) } \\
=0.0000\end{array}$} \\
\hline ST & 30.59 & 30.59 & 0.00 & \\
\hline $\mathrm{OBC}$ & 32.92 & 32.92 & 0.00 & \\
\hline Others & 10.91 & 10.91 & 0.00 & \\
\hline \multicolumn{5}{|l|}{ Household size group } \\
\hline 4 and less & 36.95 & 38.01 & +1.06 & \multirow{4}{*}{$\begin{array}{l}\text { Pearson chi2(3) } \\
=1.0416\end{array}$} \\
\hline$>4-\leq 8$ & 56.67 & 53.98 & -2.69 & \\
\hline$>8-\leq 12$ & 6.28 & 7.87 & +1.59 & \\
\hline$>12$ & 0.11 & 0.15 & +0.04 & \\
\hline
\end{tabular}

Table 2: Change in the Percentage Distribution of Households: 2007-08 to 2009-10

\begin{tabular}{|c|c|c|c|c|}
\hline Poverty Status & 2007-08 & $2009-10$ & Changes & Pearson Chi-2 \\
\hline Acutely Poor & 29.11 & 42.79 & +13.68 & \multirow{4}{*}{$\begin{array}{l}\text { Pearson chi2(3) } \\
=63.6828^{* * *}\end{array}$} \\
\hline Moderately Poor & 11.31 & 15.60 & +4.29 & \\
\hline Moderately Non-poor & 19.30 & 17.70 & -1.60 & \\
\hline Affluent & 40.27 & 23.91 & -16.36 & \\
\hline Non-Poor & 59.58 & 41.61 & -17.97 & \multirow{2}{*}{$\begin{array}{l}\text { Pearson chi2(1) } \\
=47.6951^{* * *}\end{array}$} \\
\hline Poor & 40.42 & 58.39 & +17.97 & \\
\hline
\end{tabular}

Mobility of Households by Poverty Status: 2007-08 to 2009-10

\begin{tabular}{|c|c|c|c|c|c|c|c|}
\hline \multirow{2}{*}{$\begin{array}{l}\text { Poverty Status in } \\
2007-08\end{array}$} & \multicolumn{6}{|c|}{ Poverty Status in 2009-10 } & \multirow[b]{2}{*}{ Pearson Chi-square } \\
\hline & $\begin{array}{l}\text { Acutely } \\
\text { Poor }\end{array}$ & $\begin{array}{l}\text { Moderately } \\
\text { Poor }\end{array}$ & $\begin{array}{l}\text { Moderately } \\
\text { Non-poor }\end{array}$ & Affluent & Non-poor & Poor & \\
\hline Acutely Poor & 70.24 & 13.5 & 9.85 & 6.41 & - & - & \multirow{4}{*}{$\begin{array}{l}\text { Pearson chi2(9) } \\
=78.72^{* \star *}\end{array}$} \\
\hline Moderately Poor & 64.08 & 18.30 & 16.30 & 1.31 & - & - & \\
\hline Moderately Non-poor & 35.74 & 14.88 & 26.59 & 22.79 & - & - & \\
\hline Affluent & 20.34 & 16.70 & 19.51 & 43.45 & - & & \\
\hline Non-poor & - & - & - & - & 58.56 & 41.44 & \multirow{2}{*}{$\begin{array}{l}\text { Pearson chi2(1) } \\
=38.27^{* * *}\end{array}$} \\
\hline Poor & - & - & - & - & 16.64 & 83.36 & \\
\hline
\end{tabular}

Land Ownership: 2007-08 to 2009-10

\begin{tabular}{|c|c|c|c|c|}
\hline Land owned group (in acres) & $2007-08$ & $2009-10$ & Changes & Pearson Chi-square \\
\hline Landless & 31.35 & 29.69 & -1.66 & \multirow{5}{*}{$\begin{array}{l}\text { Pearson chi2(4) } \\
=146.8763^{\star \star \star}\end{array}$} \\
\hline$>0-\leq 1$ & 27.19 & 6.07 & -21.12 & \\
\hline$>1-\leq 2$ & 25.28 & 20.66 & -4.62 & \\
\hline$>2-\leq 5$ & 11.90 & 31.20 & +19.30 & \\
\hline$>5$ & 4.28 & 12.38 & +8.10 & \\
\hline
\end{tabular}

Mobility of Households by Land Ownerships: 2007-08 to 2009-10

\begin{tabular}{|c|c|c|c|c|c|c|}
\hline \multirow{2}{*}{$\begin{array}{l}\text { Land Ownership in } \\
\text { 2007-08 (in acres) }\end{array}$} & \multicolumn{5}{|c|}{ Land Ownership in 2009--10 (in acres) } & \multirow{2}{*}{ Pearson Chi-square } \\
\hline & Landless & $>0-\leq 1$ & $>1-\leq 2$ & $>2-\leq 5$ & $>5$ & \\
\hline Landless & 73.58 & 6.39 & 8.83 & 10.06 & 1.14 & \multirow{5}{*}{$\begin{array}{l}\text { Pearson chi2 } 2(16)= \\
298.50^{* \star *}\end{array}$} \\
\hline$>0-\leq 1$ & 16.16 & 9.69 & 40.56 & 27.62 & 5.97 & \\
\hline$>1-\leq 2$ & 5.19 & 5.65 & 14.82 & 57.03 & 17.31 & \\
\hline$>2-\leq 5$ & 6.58 & 0.00 & 22.41 & 37.01 & 34.00 & \\
\hline$>5$ & 3.17 & 0.00 & 10.49 & 40.03 & 46.30 & \\
\hline
\end{tabular}

N.B. ${ }^{* *}$ indicates significance at $1 \%$. 
Table 3: Changes in Household NREGS Participation Distribution (\%): 2007-08 to 2009-10

\begin{tabular}{|c|c|c|c|c|}
\hline Household Characteristics & 2007-08 & $2009-10$ & Changes & Pearson Chi-square \\
\hline \multicolumn{5}{|l|}{ Gender of Household Heads } \\
\hline Female & 5.23 & 5.53 & +0.30 & \multirow{2}{*}{ Pearson chi2 $(1)=0.0845$} \\
\hline Male & 94.77 & 94.47 & -0.30 & \\
\hline \multicolumn{5}{|l|}{ Social Group } \\
\hline SC & 27.12 & 27.76 & +0.64 & \multirow{4}{*}{ Pearson chi2 $(3)=0.0548$} \\
\hline ST & 33.39 & 32.21 & -1.18 & \\
\hline $\mathrm{OBC}$ & 33.87 & 32.92 & -0.95 & \\
\hline Others & 5.62 & 7.11 & +1.49 & \\
\hline \multicolumn{5}{|l|}{ Poverty Status } \\
\hline Acutely Poor & 34.09 & 56.26 & +22.17 & \multirow{4}{*}{$\begin{array}{l}\text { Pearson chi2(3) = } \\
61.6195^{\star \star *}\end{array}$} \\
\hline Moderately Poor & 15.56 & 17.49 & +1.93 & \\
\hline Moderately Non-poor & 19.97 & 19.71 & -0.26 & \\
\hline Affluent & 30.37 & 6.54 & -23.83 & \\
\hline Non-Poor & 50.34 & 26.25 & -24.09 & \multirow{2}{*}{$\begin{array}{l}\text { Pearson chi2(1) }= \\
42.5181^{\star \star \star}\end{array}$} \\
\hline Poor & 49.66 & 73.75 & +24.09 & \\
\hline \multicolumn{5}{|l|}{ Land owned group (in acres) } \\
\hline Landless & 25.85 & 21.10 & -4.75 & \multirow{5}{*}{$\begin{array}{l}\text { Pearson chi2(4) = } \\
114.2382^{* * *}\end{array}$} \\
\hline$>0-\leq 1$ & 30.13 & 10.03 & -20.10 & \\
\hline$>1-\leq 2$ & 30.46 & 20.35 & -10.11 & \\
\hline$>2-\leq 5$ & 10.67 & 37.25 & +26.58 & \\
\hline$>5$ & 2.89 & 11.27 & +8.38 & \\
\hline \multicolumn{5}{|l|}{ Household size group } \\
\hline 4 and less & 38.39 & 40.11 & +1.72 & \multirow{4}{*}{ Pearson chi2 $(3)=2.6313$} \\
\hline$>4-\leq 8$ & 54.45 & 49.57 & -4.88 & \\
\hline$>8-\leq 12$ & 7.08 & 10.02 & +2.94 & \\
\hline$>12$ & 0.09 & 0.31 & +0.22 & \\
\hline All & 67.81 & 47.74 & -20.07 & \\
\hline
\end{tabular}

N.B. ${ }^{* * *}$ indicates significance at $1 \%$. 
Raghbendra Jha, Raghav Gaiha, Manoj K. Pandey \& Shylashri Shankar

Table 4: \% Distribution of Four Types of Households by Households Characteristics in base year 2007-08

\begin{tabular}{|c|c|c|c|c|}
\hline Household Characteristics & Type I Households & Type II Households & Type III Households & Type IV Households \\
\hline \multicolumn{5}{|l|}{ Gender of Household Heads } \\
\hline Female & $\begin{array}{l}14.29 \\
(2.00)\end{array}$ & $\begin{array}{l}21.98 \\
(4.01)\end{array}$ & $\begin{array}{c}0.00 \\
(0.00)\end{array}$ & $\begin{array}{l}63.73 \\
(5.85)\end{array}$ \\
\hline Male & $\begin{array}{c}30.24 \\
(98.00) \\
\end{array}$ & $\begin{array}{c}22.70 \\
(95.99) \\
\end{array}$ & $\begin{array}{c}2.73 \\
(100.00) \\
\end{array}$ & $\begin{array}{c}44.33 \\
(94.15) \\
\end{array}$ \\
\hline \multicolumn{5}{|l|}{ Social Group } \\
\hline SC & $\begin{array}{c}25.60 \\
(22.14)\end{array}$ & $\begin{array}{c}22.58 \\
(25.47)\end{array}$ & $\begin{array}{c}2.52 \\
(24.67)\end{array}$ & $\begin{array}{c}49.3 \\
(27.94)\end{array}$ \\
\hline ST & $\begin{array}{c}21.78 \\
(22.52)\end{array}$ & $\begin{array}{c}27.94 \\
(37.69)\end{array}$ & $\begin{array}{c}4.20 \\
(49.19)\end{array}$ & $\begin{array}{c}46.07 \\
(31.23)\end{array}$ \\
\hline $\mathrm{OBC}$ & $\begin{array}{c}28.23 \\
(31.42) \\
\end{array}$ & $\begin{array}{l}24.04 \\
(34.9)\end{array}$ & $\begin{array}{c}2.02 \\
(25.41) \\
\end{array}$ & $\begin{array}{c}45.72 \\
(33.35)\end{array}$ \\
\hline Others & $\begin{array}{c}64.86 \\
(23.92)\end{array}$ & $\begin{array}{c}4.02 \\
(1.93)\end{array}$ & $\begin{array}{c}0.17 \\
(0.73)\end{array}$ & $\begin{array}{l}30.94 \\
(7.48)\end{array}$ \\
\hline \multicolumn{5}{|l|}{ Poverty Status } \\
\hline Acutely Poor & $\begin{array}{c}18.08 \\
(17.79)\end{array}$ & $\begin{array}{c}25.32 \\
(32.51)\end{array}$ & $\begin{array}{c}2.52 \\
(28.04)\end{array}$ & $\begin{array}{c}54.08 \\
(34.89)\end{array}$ \\
\hline Moderately Poor & $\begin{array}{c}6.70 \\
(2.56)\end{array}$ & $\begin{array}{c}40.17 \\
(20.04)\end{array}$ & $\begin{array}{c}0.00 \\
(0.00)\end{array}$ & $\begin{array}{c}53.13 \\
(13.32)\end{array}$ \\
\hline Moderately Non-poor & $\begin{array}{c}25.47 \\
(16.62) \\
\end{array}$ & $\begin{array}{c}22.82 \\
(19.43) \\
\end{array}$ & $\begin{array}{c}4.38 \\
(32.39) \\
\end{array}$ & $\begin{array}{c}47.33 \\
(20.24) \\
\end{array}$ \\
\hline Affluent & $\begin{array}{c}46.30 \\
(63.03)\end{array}$ & $\begin{array}{c}15.78 \\
(28.03)\end{array}$ & $\begin{array}{c}2.57 \\
(39.57)\end{array}$ & $\begin{array}{c}35.36 \\
(31.55)\end{array}$ \\
\hline Non-Poor & $\begin{array}{c}39.55 \\
(79.64)\end{array}$ & $\begin{array}{c}18.06 \\
(47.45)\end{array}$ & $\begin{array}{c}3.16 \\
(71.96)\end{array}$ & $\begin{array}{c}39.24 \\
(51.79)\end{array}$ \\
\hline Poor & $\begin{array}{c}14.90 \\
(20.36) \\
\end{array}$ & $\begin{array}{c}29.47 \\
(52.55) \\
\end{array}$ & $\begin{array}{c}1.81 \\
(28.04) \\
\end{array}$ & $\begin{array}{c}53.82 \\
(48.21) \\
\end{array}$ \\
\hline \multicolumn{5}{|l|}{ Land Owned Group (in acres) } \\
\hline Landless & $\begin{array}{c}42.35 \\
(44.88)\end{array}$ & $\begin{array}{c}21.30 \\
(29.45)\end{array}$ & $\begin{array}{c}1.74 \\
(20.85)\end{array}$ & $\begin{array}{c}34.62 \\
(24.05)\end{array}$ \\
\hline$>0-\leq 1$ & $\begin{array}{l}24.50 \\
(22.52)\end{array}$ & $\begin{array}{c}25.25 \\
(30.28)\end{array}$ & $\begin{array}{c}0.37 \\
(3.81)\end{array}$ & $\begin{array}{c}49.88 \\
(30.05)\end{array}$ \\
\hline$>1-\leq 2$ & $\begin{array}{c}12.98 \\
(11.09)\end{array}$ & $\begin{array}{c}24.04 \\
(26.80)\end{array}$ & $\begin{array}{c}5.31 \\
(51.41)\end{array}$ & $\begin{array}{c}57.67 \\
(32.30)\end{array}$ \\
\hline$>2-\leq 5$ & $\begin{array}{c}34.79 \\
(14.00)\end{array}$ & $\begin{array}{l}18.04 \\
(9.47)\end{array}$ & $\begin{array}{c}4.41 \\
(20.07)\end{array}$ & $\begin{array}{c}42.76 \\
(11.28)\end{array}$ \\
\hline$>5$ & $\begin{array}{l}51.91 \\
(7.51)\end{array}$ & $\begin{array}{l}21.22 \\
(4.00)\end{array}$ & $\begin{array}{c}2.35 \\
(3.85)\end{array}$ & $\begin{array}{l}24.51 \\
(2.32)\end{array}$ \\
\hline \multicolumn{5}{|l|}{ Household Size Group } \\
\hline 4 and less & $\begin{array}{c}26.41 \\
(32.99) \\
\end{array}$ & $\begin{array}{c}24.28 \\
(39.56) \\
\end{array}$ & $\begin{array}{c}3.15 \\
(44.50) \\
\end{array}$ & $\begin{array}{c}46.16 \\
(37.79) \\
\end{array}$ \\
\hline$>4-\leq 8$ & $\begin{array}{c}33.01 \\
(63.23) \\
\end{array}$ & $\begin{array}{c}21.16 \\
(52.87) \\
\end{array}$ & $\begin{array}{c}1.84 \\
(39.92) \\
\end{array}$ & $\begin{array}{c}43.99 \\
(55.24)\end{array}$ \\
\hline$>8-\leq 12$ & $\begin{array}{l}17.81 \\
(3.78)\end{array}$ & $\begin{array}{l}27.33 \\
(7.57)\end{array}$ & $\begin{array}{c}5.68 \\
(13.66)\end{array}$ & $\begin{array}{l}49.17 \\
(6.84)\end{array}$ \\
\hline$>12$ & $\begin{array}{c}0.00 \\
(0.00) \\
\end{array}$ & $\begin{array}{c}0.00 \\
(0.00) \\
\end{array}$ & $\begin{array}{l}45.98 \\
(1.93) \\
\end{array}$ & $\begin{array}{l}54.02 \\
(0.13) \\
\end{array}$ \\
\hline All & 29.58 & 22.67 & 2.61 & 45.13 \\
\hline
\end{tabular}

N.B. Figures in parentheses are the column percentages. Type I households: those who never participated; Type II households: Those who participated in 2007-08 but not in 2009-10; Type III households: Those who participated first time in 2009-10; Type IV households: Those who participated in both the years 
Table: 5. Descriptive Statistics of Household's CPIAL adjusted Per Capita Monthly Consumption Expenditure and Per Capita Income Net of NREGS Earnings: 2007-08 and 2009-10

\begin{tabular}{|c|c|c|c|c|c|c|c|}
\hline \multirow{2}{*}{$\begin{array}{l}\text { Type of } \\
\text { Households }\end{array}$} & \multicolumn{2}{|c|}{$\begin{array}{c}\text { Mean } \\
\text { (Standard Deviation) }\end{array}$} & \multirow{2}{*}{$\begin{array}{l}\text { Paired t-test } \\
\text { for difference } \\
\text { of means: } \\
2007-08 \text { and } \\
2009-10\end{array}$} & \multicolumn{2}{|c|}{$\begin{array}{c}\text { Median } \\
\text { (Standard Deviation) }\end{array}$} & \multicolumn{2}{|c|}{$\begin{array}{c}\text { Tests for equality of } \\
\text { median/distribution: } \\
2007-08 \text { and 2009-10 }\end{array}$} \\
\hline & $2007-08$ & $2009-10$ & & 2007-08 & $2009-10$ & $\begin{array}{c}\text { Signed } \\
\text { Rank test }\end{array}$ & Sign test \\
\hline \multicolumn{8}{|c|}{ CPIAL adjusted Monthly Per Capita Consumption Expenditure } \\
\hline $\begin{array}{l}\text { Type } \\
\text { households }\end{array}$ & $\begin{array}{c}811.83 \\
(507.02)\end{array}$ & $\begin{array}{c}676.51 \\
(304.52)\end{array}$ & $\begin{aligned} & t(74) \\
= & 3.12^{\star * *}\end{aligned}$ & $\begin{array}{c}692.13 \\
(507.02)\end{array}$ & $\begin{array}{c}642.69 \\
(304.52)\end{array}$ & $\begin{array}{c}Z= \\
2.40^{* *}\end{array}$ & $\begin{array}{c}P= \\
0.1778\end{array}$ \\
\hline $\begin{array}{l}\text { Type } \\
\text { households }\end{array}$ & $\begin{array}{c}500.25 \\
(229.58)\end{array}$ & $\begin{array}{c}562.59 \\
(743.47)\end{array}$ & $\begin{aligned} & t(103) \\
= & 2.38^{\star \star *}\end{aligned}$ & $\begin{array}{c}437.67 \\
(229.58)\end{array}$ & $\begin{array}{c}395.98 \\
(743.47)\end{array}$ & $\begin{array}{c}Z= \\
5.14^{* * *}\end{array}$ & $P=0.0000^{* * *}$ \\
\hline $\begin{array}{l}\text { Type III } \\
\text { households }\end{array}$ & $\begin{array}{c}543.75 \\
(165.78)\end{array}$ & $\begin{array}{c}380.62 \\
(109.31)\end{array}$ & $\begin{aligned} & t(21) \\
= & 2.82^{* * *}\end{aligned}$ & $\begin{array}{c}565.43 \\
(165.78)\end{array}$ & $\begin{array}{c}379.65 \\
(109.31)\end{array}$ & $\begin{array}{c}Z= \\
2.52^{* *}\end{array}$ & $P=0.0669^{*}$ \\
\hline $\begin{array}{ll}\text { Type } & \text { IV } \\
\text { households } & \end{array}$ & $\begin{array}{c}503.26 \\
(237.67)\end{array}$ & $\begin{array}{c}391.05 \\
(206.00)\end{array}$ & $\begin{aligned} & t(274) \\
= & 4.31^{* * *}\end{aligned}$ & $\begin{array}{c}470.42 \\
(237.67)\end{array}$ & $\begin{array}{c}360.43 \\
(206.00)\end{array}$ & $\begin{array}{c}Z= \\
7.25^{\star \star *}\end{array}$ & $P=0.0000^{\star * *}$ \\
\hline ALL & $\begin{array}{c}594.91 \\
(364.75)\end{array}$ & $\begin{array}{c}514.12 \\
(431.98)\end{array}$ & $\begin{aligned} & t(475) \\
= & 6.06^{\star * \star}\end{aligned}$ & $\begin{array}{c}514.25 \\
(364.75)\end{array}$ & $\begin{array}{c}406.80 \\
(431.98)\end{array}$ & $\begin{array}{c}Z= \\
9.21^{\star * *}\end{array}$ & $P=0.0000^{* * *}$ \\
\hline \multicolumn{8}{|c|}{ CPIAL adjusted Per Capita Income Net of NREGS Earnings } \\
\hline $\begin{array}{l}\text { Type } \\
\text { households }\end{array}$ & $\begin{array}{c}1370.57 \\
(1236.18)\end{array}$ & $\begin{array}{c}868.70 \\
(592.34)\end{array}$ & $\begin{aligned} & t(74) \\
= & 3.34^{\star * \star}\end{aligned}$ & $\begin{array}{c}1188.19 \\
(1236.18)\end{array}$ & $\begin{array}{c}815.74 \\
(592.34)\end{array}$ & $\begin{array}{c}Z= \\
3.59^{* *}\end{array}$ & $\begin{array}{c}P= \\
0.0026^{* * *}\end{array}$ \\
\hline $\begin{array}{l}\text { Type } \\
\text { households }\end{array}$ & $\begin{array}{c}539.33 \\
(348.89)\end{array}$ & $\begin{array}{c}433.25 \\
(245.97)\end{array}$ & $\begin{aligned} & t(103) \\
= & 4.35^{\star * *}\end{aligned}$ & $\begin{array}{c}443.75 \\
(348.89)\end{array}$ & $\begin{array}{c}382.05 \\
(245.97)\end{array}$ & $\begin{array}{c}Z= \\
4.34^{* * *}\end{array}$ & $P=0.0011^{* * *}$ \\
\hline $\begin{array}{l}\text { Type III } \\
\text { households }\end{array}$ & $\begin{array}{c}625.29 \\
(196.48)\end{array}$ & $\begin{array}{l}352.57 \\
(95.14)\end{array}$ & $\begin{aligned} & t(21) \\
= & 3.47^{\star * *}\end{aligned}$ & $\begin{array}{c}596.88 \\
(196.48)\end{array}$ & $\begin{array}{l}341.13 \\
(95.14)\end{array}$ & $\begin{array}{c}Z= \\
2.78^{\star *}\end{array}$ & $P=0.0669^{*}$ \\
\hline $\begin{array}{ll}\text { Type } & \text { IV } \\
\text { households }\end{array}$ & $\begin{array}{c}524.28 \\
(317.00)\end{array}$ & $\begin{array}{c}342.15 \\
(197.13)\end{array}$ & $\begin{aligned} & t(274) \\
= & 9.99^{* * *}\end{aligned}$ & $\begin{array}{c}453.57 \\
(317.00)\end{array}$ & $\begin{array}{c}285.43 \\
(197.13)\end{array}$ & $\begin{array}{c}Z= \\
9.43^{* * *}\end{array}$ & $P=0.0000^{\star * *}$ \\
\hline ALL & $\begin{array}{c}780.67 \\
(816.91)\end{array}$ & $\begin{array}{c}518.84 \\
(432.16)\end{array}$ & $\begin{aligned} & t(475) \\
= & 8.63^{* * *}\end{aligned}$ & $\begin{array}{c}546.88 \\
(816.91)\end{array}$ & $\begin{array}{c}366.82 \\
(432.16)\end{array}$ & $\begin{array}{c}Z= \\
11.07^{* * *}\end{array}$ & $P=0.0000^{* * *}$ \\
\hline
\end{tabular}

Note: Type I households: those who never participated; Type II households: Those who participated in 2007-08 but not in 2009-10; Type III households: Those who participated first time in 2009-10; Type IV households: Those who participated in both the years. ${ }^{* * *, * *,}$, refer to significance at the $1 \%, 5 \%$ and $10 \%$ level, respectively. $t(\mathrm{~m})$ denotes for t-statistics with $\mathrm{m}$ degrees of freedom. $\mathrm{Z}$ refers to Z-statistics and $P$ refers to the probability of number of positive outcome (say $X$ ) larger than the observed positive outcome (say $x$ in a sample of $n$ with probability of success $p)=$ Binomial $(n, X>=x, p=0.5)$. Positive values of $t$ and $z$ suggest that base year 2007-08 values (mean or median) are significantly higher than those in 2009-10. 
Table 6: Variation in changes in income across four types of households: Regression Estimates from OLS with Robust Standard Errors

\begin{tabular}{|l|c|c|}
\hline Dependent Variable & $\begin{array}{c}\text { \%change in Per Capita } \\
\text { Monthly Expenditure }\end{array}$ & $\begin{array}{c}\text { \%change in Per Capita Monthly } \\
\text { Income Net of NREGS Earnings }\end{array}$ \\
\hline Explanatory Variables & Coefficients (t-values) & Coefficients (t-values) \\
\hline Type II households: Dummy\# & $8.37(0.25)$ & $-25.62(-1.41)$ \\
\hline Type III households: Dummy\# & $-49.60^{* *}(-3.23)$ & $-49.08^{* *}(-3.00)$ \\
\hline Type IV households: Dummy\# & $-35.14^{* * *}(-3.50)$ & $-35.32^{*}(-1.81)$ \\
\hline Social Group Dummy: SC+ & $-17.35(-1.39)$ & $-50.33(-1.25)$ \\
\hline Social Group Dummy: ST+ & $3.42(0.14)$ & $-55.52(-1.37)$ \\
\hline Social Group Dummy: OBC+ & $-24.01^{*}(-1.87)$ & $-60.67 \mathrm{w}(-1.61)$ \\
\hline Per Capita Monthly Expenditure: 2007-08 & $-0.08^{* * *}(-4.43)$ & $-0.04^{* *}(-2.55)$ \\
\hline Per Capita Monthly Income Net of NREGS Earnings: 2007-08 & & $-2.84(-0.97)$ \\
\hline Household Size: 2007-08 & $-2.56(-0.92)$ & $4.37(0.65)$ \\
\hline Change in Household Size: 2007-08 and 2009-10 & $-25.82(-1.15)$ & 111.26 \\
\hline Constant & 88.36 & 475 \\
\hline Number of observations & 476 & $\mathrm{~F}(9,465)=3.77^{* * *}$ \\
\hline F-values & $\mathrm{F}(9,466)=4.91^{* * *}$ & 0.1609 \\
\hline R-squared & 0.1240 & 74.993 \\
\hline Root MSE & 101.05 & \\
\hline
\end{tabular}

N.B: +: Social Group Dummy for Others is the omitted group. \# Type I households: Dummy is the reference group. ${ }^{* * *},{ }^{* *},{ }^{*}$ refer to significance at the $1 \%, 5 \%$ and $10 \%$ level, respectively; and $w$ denotes weakly significant (>10\% level). Figures in the parenthesis are the t-values based on robust standard errors. Detailed definition of the variables used in the analysis can be obtained in Annex Table A.2. 
Table 7: Descriptive Statistics for Household's Share of Per Capita Income from Agricultural Sources and Nonagricultural (excluding NREGS) Sources and \% Changes in these Shares by Types of Household

\begin{tabular}{|c|c|c|c|c|c|c|c|c|}
\hline \multirow[t]{2}{*}{ Type of Households } & \multicolumn{2}{|c|}{$\begin{array}{l}\text { Share of per capita } \\
\text { annual income from } \\
\text { agricultural sources } \\
\text { in total per capita } \\
\text { income in 2007-08 }\end{array}$} & \multicolumn{2}{|c|}{$\begin{array}{l}\% \text { change (increase) } \\
\text { in household's share } \\
\text { of per capita income } \\
\text { from agricultural sources } \\
\text { over } 2007-08 \text { \& } 2009-10\end{array}$} & \multicolumn{2}{|c|}{$\begin{array}{l}\text { share of per capita } \\
\text { annual income from } \\
\text { non-agricultural } \\
\text { (excluding nregs) } \\
\text { sources in total per capita } \\
\text { income in 2007-08 }\end{array}$} & \multicolumn{2}{|c|}{$\begin{array}{l}\text { \%change (increase) in } \\
\text { household's share of } \\
\text { per capita income from } \\
\text { non-agricultural } \\
\text { (excluding nregs) } \\
\text { sources over } \\
2007-08 \text { \& 2009-10 }\end{array}$} \\
\hline & $\begin{array}{l}\text { Mean } \\
{[S D]}\end{array}$ & Median & $\begin{array}{c}\text { Mean } \\
{[S D]}\end{array}$ & Median & $\begin{array}{l}\text { Mean } \\
{[S D]}\end{array}$ & Median & $\begin{array}{l}\text { Mean } \\
{[S D]}\end{array}$ & Median \\
\hline \begin{tabular}{|l} 
Type I \\
households
\end{tabular} & $\begin{array}{c}14.88 \\
{[26.97]}\end{array}$ & 1.08 & $\begin{array}{c}2.66 \\
{[23.97]}\end{array}$ & 0.00 & $\begin{array}{c}85.12 \\
{[26.97]}\end{array}$ & 98.92 & $\begin{array}{c}-2.66 \\
{[23.97]}\end{array}$ & 0.00 \\
\hline \begin{tabular}{|l} 
Type II \\
households
\end{tabular} & $\begin{array}{c}27.96 \\
{[27.77]}\end{array}$ & 22.68 & $\begin{array}{c}3.77 \\
{[27.63]}\end{array}$ & 3.15 & $\begin{array}{c}60.31 \\
{[30.43]}\end{array}$ & 61.86 & $\begin{array}{c}7.96 \\
{[29.49]}\end{array}$ & 8.22 \\
\hline \begin{tabular}{|l} 
Type III \\
households
\end{tabular} & $\begin{array}{c}44.12 \\
{[36.62]}\end{array}$ & 30.31 & $\begin{array}{c}-7.62 \\
{[26.55]}\end{array}$ & 3.85 & $\begin{array}{c}55.88 \\
{[36.62]}\end{array}$ & 69.69 & $\begin{array}{c}-5.56 \\
{[25.08]}\end{array}$ & -8.38 \\
\hline \begin{tabular}{|l} 
Type IV \\
households
\end{tabular} & $\begin{array}{c}31.23 \\
{[27.11]}\end{array}$ & 25.53 & $\begin{array}{c}1.40 \\
{[27.66]}\end{array}$ & 2.01 & $\begin{array}{c}53.89 \\
{[28.77]}\end{array}$ & 57.03 & $\begin{array}{c}-1.09 \\
{[30.41]}\end{array}$ & -2.75 \\
\hline
\end{tabular}

Note: Type I households: those who never participated; Type II households: Those who participated in 2007-08 but not in 2009-10; Type III households: Those who participated first time in 2009-10; Type IV households: Those who participated in both the years. SD= Standard Deviation 
Table 8: Repeated t-test for differences in the mean shares of base years and changes in the share of agricultural and non-agricultural sources by types of households

\begin{tabular}{|l|c|c|c|c|}
\hline \multirow{2}{*}{ Bonferroni multiple-mean comparison test } & \multicolumn{3}{|c|}{ T-statistics for differences of means for } \\
\cline { 2 - 5 } & $\begin{array}{c}\text { Share of per capita } \\
\text { annual income from } \\
\text { agricultural sources } \\
\text { in total per capita } \\
\text { income in 2007-08 }\end{array}$ & $\begin{array}{c}\text { \%change in } \\
\text { household's } \\
\text { share of per } \\
\text { capita income } \\
\text { from agricultural } \\
\text { sources }\end{array}$ & $\begin{array}{c}\text { Share of per capita } \\
\text { annual income from } \\
\text { non-agricultural } \\
\text { (excluding NREGS) } \\
\text { sources in total per } \\
\text { capita income } \\
2007-08\end{array}$ & $\begin{array}{c}\text { \% Change in } \\
\text { household's share of } \\
\text { per capita income } \\
\text { from non-agricultural } \\
\text { (excluding NREGS) } \\
\text { sources }\end{array}$ \\
\hline Type II households-Type I households & $13.08^{* * *}$ & $1.11^{* * *}$ & $-24.81^{* * *}$ & $10.62^{* * *}$ \\
\hline Type III households-Type I households & $29.24^{* * *}$ & $-10.28^{* * *}$ & $-29.24^{* * *}$ & $-2.90^{* * *}$ \\
\hline Type IV households-Type I households & $16.34^{* * *}$ & $-1.26^{* * *}$ & $-31.22^{* * *}$ & $1.58^{* * *}$ \\
\hline Type III households-Type II households & $16.16^{* * *}$ & $-11.38^{* * *}$ & $-4.43^{* * *}$ & $-13.52^{* * *}$ \\
\hline Type IV households-Type II households & $3.26^{* * *}$ & $-2.36^{* * *}$ & $-6.42^{* * *}$ & $-9.04^{* * *}$ \\
\hline Type IV households-Type III households & $-12.90^{* * *}$ & $9.02^{* * *}$ & $-1.99^{* * *}$ & $4.47^{* * *}$ \\
\hline
\end{tabular}

Note: Type I households: those who never participated; Type II households: Those who participated in 2007-08 but not in 2009-10; Type III households: Those who participated first time in 2009-10; Type IV households: Those who participated in both the years.

${ }^{* * *}$ refers to significance at the $1 \%$ level. 
Table 9: Estimation of Switches into and out of NREGS during 2007-08 and 2009-10 in Rajasthan: Multinomial Logit Coefficient Estimates

\begin{tabular}{|c|c|c|c|}
\hline Dependent variable outcomes & $\begin{array}{c}\text { Households who } \\
\text { withdrew participation } \\
\text { (Type II) }\end{array}$ & $\begin{array}{l}\text { Households who } \\
\text { participated first time } \\
\text { (Type III) }\end{array}$ & $\begin{array}{l}\text { Household who } \\
\text { continued } \\
\text { participation } \\
\text { (Type IV) }\end{array}$ \\
\hline Explanatory variables & $\begin{array}{l}\text { Coefficient } \\
\text { (z-value) }\end{array}$ & $\begin{array}{l}\text { Coefficient } \\
\text { (z-value) }\end{array}$ & $\begin{array}{l}\text { Coefficient } \\
\text { (z-value) }\end{array}$ \\
\hline Social group dummy: SC & $\begin{array}{l}2.44^{* \star *} \\
(3.10)\end{array}$ & $\begin{array}{l}3.73^{\star *} \\
(2.56)\end{array}$ & $\begin{array}{c}1.06^{w} \\
(1.58)\end{array}$ \\
\hline Social group dummy: ST & $\begin{array}{l}2.85^{* * *} \\
(3.61)\end{array}$ & $\begin{array}{l}4.70^{* \star *} \\
(3.55)\end{array}$ & $\begin{array}{r}1.19^{*} \\
(1.76)\end{array}$ \\
\hline Social group dummy: OBC & $\begin{array}{l}2.51^{* * *} \\
(3.05)\end{array}$ & $\begin{array}{l}3.65^{* * *} \\
(2.97)\end{array}$ & $\begin{array}{r}1.09^{w} \\
(1.62)\end{array}$ \\
\hline$\%$ adults in the household: $2007-08$ & $\begin{array}{c}-0.01 \\
(-0.55)\end{array}$ & $\begin{array}{c}0.02 \\
(0.98)\end{array}$ & $\begin{array}{c}-0.01 \\
(-0.87)\end{array}$ \\
\hline$\Delta \%$ adult in the household: $2007-08$ to $2009-10$ & $\begin{array}{c}0.01 \\
(0.47)\end{array}$ & $\begin{array}{c}0.06^{* *} \\
(1.96)\end{array}$ & $\begin{array}{c}0.02 \\
(0.98)\end{array}$ \\
\hline Land owned by household: 2007-08 & $\begin{array}{c}-0.13 \\
(-1.08)\end{array}$ & $\begin{array}{l}0.09 \\
(0.72)\end{array}$ & $\begin{array}{l}-0.22^{* *} \\
(-2.08)\end{array}$ \\
\hline$\Delta$ Land owned by household: $2007-08$ to $2009-10$ & $\begin{array}{c}0.00 \\
(-0.05)\end{array}$ & $\begin{array}{c}-0.04 \\
(-0.55)\end{array}$ & $\begin{array}{c}-0.02 \\
(-0.52)\end{array}$ \\
\hline Ratio of NREG to AGR wage rate in village: $2007-08$ & $\begin{array}{l}4.53^{* *} \\
(2.14)\end{array}$ & $\begin{array}{r}5.99^{*} \\
(1.86)\end{array}$ & $\begin{array}{c}2.66 \\
(1.26)\end{array}$ \\
\hline $\begin{array}{l}\Delta \text { Ratio of NREG to AGR wage rate in village: } 2007-08 \text { to } \\
2009-10\end{array}$ & $\begin{array}{c}1.73 \\
(1.08)\end{array}$ & $\begin{array}{l}5.73^{* *} \\
(2.45)\end{array}$ & $\begin{array}{c}1.26 \\
(0.79)\end{array}$ \\
\hline Average distance of NREG sites from the village: $2007-08$ & $\begin{array}{c}-0.23 \\
(-0.51)\end{array}$ & $\begin{array}{c}0.04 \\
(0.06)\end{array}$ & $\begin{array}{c}-0.35 \\
(-0.87)\end{array}$ \\
\hline $\begin{array}{l}\text { Per Capita Annual Earnings from Non-agricultural sources } \\
\text { net of NREGS earnings in village: } 2007-08\end{array}$ & $\begin{array}{l}-1.6 \times 10^{-4 * *} \\
(-2.30)\end{array}$ & $\begin{array}{c}0.00 \\
(-0.98)\end{array}$ & $\begin{array}{l}-3.7 \times 10^{-4 * * *} \\
(-5.11)\end{array}$ \\
\hline $\begin{array}{l}\Delta \text { per capita annual earnings from non-agricultural sources } \\
\text { net of NREGS earnings in village: } 2007-08 \text { to } 2009-10\end{array}$ & $\begin{array}{c}1.56 \\
(1.21)\end{array}$ & $\begin{array}{r}3.11^{*} \\
(1.83)\end{array}$ & $\begin{array}{c}1.20 \\
(1.00)\end{array}$ \\
\hline Constant & $\begin{array}{c}-4.07 \\
(-1.40)\end{array}$ & $\begin{array}{c}-11.13^{* *} \\
(-2.22) \\
\end{array}$ & $\begin{array}{c}1.79 \\
(0.68) \\
\end{array}$ \\
\hline Number of observations & \multicolumn{3}{|c|}{456} \\
\hline Wald chi-square(36) & \multicolumn{3}{|c|}{$173.42^{\star \star \star}$} \\
\hline Pseudo R-square & \multicolumn{3}{|c|}{0.1718} \\
\hline Log pseudolikelihood & \multicolumn{3}{|c|}{-433.8825} \\
\hline
\end{tabular}

Note: Type I households (households who never participated) are the base (reference) category. Type I households: those who never participated; Type II households: Those who participated in 2007-08 but not in 2009-10; Type III households: Those who participated first time in 2009-10; Type IV households: Those who participated in both the years. ${ }^{* * *},{ }^{* *},{ }^{*}$ refer to significance at the $1 \%, 5 \%$ and $10 \%$ level, respectively; and w denotes weakly significant (>10\% level). Figures in the parenthesis are the z-values. 
Table 10: Estimation of Switches into and out of NREGS during 2007-08 and 2009-10 in Rajasthan: Multinomial Logit Marginal Effect Estimates

\begin{tabular}{|c|c|c|c|c|}
\hline Outcomes & $\begin{array}{l}\text { Households who } \\
\text { Never Participated } \\
\text { (Type I) }\end{array}$ & $\begin{array}{l}\text { Households who } \\
\text { Withdrew } \\
\text { Participation } \\
\text { (Type II) }\end{array}$ & $\begin{array}{l}\text { Households who } \\
\text { Participated First } \\
\text { time (Type III) }\end{array}$ & $\begin{array}{l}\text { Household who } \\
\text { Continued } \\
\text { Participation (Type } \\
\text { IV) }\end{array}$ \\
\hline Explanatory variables & $\begin{array}{c}\text { ME } \\
\text { (z-value) }\end{array}$ & $\begin{array}{c}\text { ME } \\
\text { (z-value) }\end{array}$ & $\begin{array}{c}\text { ME } \\
\text { (z-value) }\end{array}$ & $\begin{array}{c}\text { ME } \\
\text { (z-value) }\end{array}$ \\
\hline Social group dummy: SC & $\begin{array}{l}-0.22^{* * *} \\
(-3.46)\end{array}$ & $\begin{array}{r}0.31^{*} \\
(1.80)\end{array}$ & $\begin{array}{l}0.07 \\
(0.82)\end{array}$ & $\begin{array}{c}-0.16 \\
(-0.99)\end{array}$ \\
\hline Social group dummy: ST & $\begin{array}{l}-0.26^{\star * *} \\
(-3.67)\end{array}$ & $\begin{array}{l}0.35^{* *} \\
(2.11)\end{array}$ & $\begin{array}{c}0.10 \\
(1.15)\end{array}$ & $\begin{array}{c}-0.19 \\
(-1.25)\end{array}$ \\
\hline Social group dummy: OBC & $\begin{array}{l}-0.24^{* * *} \\
(-3.25)\end{array}$ & $\begin{array}{r}0.32^{*} \\
(1.87)\end{array}$ & $\begin{array}{c}0.06 \\
(1.02)\end{array}$ & $\begin{array}{c}-0.14 \\
(-0.82)\end{array}$ \\
\hline$\%$ adults in the household: $2007-08$ & $\begin{array}{c}0.00 \\
(0.78)\end{array}$ & $\begin{array}{c}0.00 \\
(-0.04)\end{array}$ & $\begin{array}{c}0.00 \\
(1.42)\end{array}$ & $\begin{array}{c}0.00 \\
(-0.83)\end{array}$ \\
\hline $\begin{array}{l}\Delta \% \text { adult in the household: } 2007-08 \text { to } \\
2009-10\end{array}$ & $\begin{array}{c}0.00 \\
(-0.91)\end{array}$ & $\begin{array}{c}0.00 \\
(-0.27)\end{array}$ & $\begin{array}{r}0.00 \\
(1.44) \\
\end{array}$ & $\begin{array}{l}0.00 \\
(0.84) \\
\end{array}$ \\
\hline Land owned by household: $2007-08$ & $\begin{array}{r}0.03^{*} \\
(1.90)\end{array}$ & $\begin{array}{l}0.00 \\
(0.14)\end{array}$ & $\begin{array}{l}0.003^{* *} \\
(2.14)\end{array}$ & $\begin{array}{r}-0.04^{*} \\
(-1.76)\end{array}$ \\
\hline $\begin{array}{l}\Delta \text { Land owned by household: } 2007-08 \text { to } \\
2009-10\end{array}$ & $\begin{array}{l}0.00 \\
(0.38)\end{array}$ & $\begin{array}{l}0.00 \\
(0.40)\end{array}$ & $\begin{array}{c}0.00 \\
(-0.40)\end{array}$ & $\begin{array}{c}-0.01 \\
(-0.73)\end{array}$ \\
\hline $\begin{array}{l}\text { Ratio of NREG to AGR wage rate in } \\
\text { village: } 2007-08\end{array}$ & $\begin{array}{r}-0.57^{*} \\
(-1.75)\end{array}$ & $\begin{array}{l}0.48^{* *} \\
(2.18)\end{array}$ & $\begin{array}{c}0.05 \\
(1.35)\end{array}$ & $\begin{array}{c}0.04 \\
(0.12)\end{array}$ \\
\hline $\begin{array}{l}\triangle \text { Ratio of NREG to AGR wage rate in } \\
\text { village: } 2007-08 \text { to } 2009-10\end{array}$ & $\begin{array}{c}-0.26 \\
(-1.01)\end{array}$ & $\begin{array}{c}0.14 \\
(0.75)\end{array}$ & $\begin{array}{l}0.07^{* *} \\
(2.01)\end{array}$ & $\begin{array}{c}0.05 \\
(0.19)\end{array}$ \\
\hline $\begin{array}{l}\text { Average distance of NREG Sites from the } \\
\text { village: } 2007-08\end{array}$ & $\begin{array}{c}0.05 \\
(0.75)\end{array}$ & $\begin{array}{l}0.00 \\
(0.03)\end{array}$ & $\begin{array}{l}0.00 \\
(0.49)\end{array}$ & $\begin{array}{c}-0.06 \\
(-0.92)\end{array}$ \\
\hline $\begin{array}{l}\text { Per capita annual earnings from non- } \\
\text { agricultural sources net of NREGS } \\
\text { earnings in village: } 2007-08\end{array}$ & $\begin{array}{l}5.0 \times 10^{-5 * * *} \\
(4.08)\end{array}$ & $\begin{array}{l}2.0 \times 10^{-5 \mathrm{w}} \\
(1.61)\end{array}$ & $\begin{array}{l}0.00 \\
(0.43)\end{array}$ & $\begin{array}{l}-7.0 \times 10^{-5 * * *} \\
(-4.63)\end{array}$ \\
\hline $\begin{array}{l}\Delta \text { per capita annual earnings from } \\
\text { non-agricultural sources net of NREGS } \\
\text { earnings in village: } 2007-08 \text { to } 2009-10\end{array}$ & $\begin{array}{l}-0.23 \\
(-1.11)\end{array}$ & $\begin{array}{c}0.13 \\
(1.02)\end{array}$ & $\begin{array}{c}0.03^{w} \\
(1.63)\end{array}$ & $\begin{array}{c}0.07 \\
(0.45)\end{array}$ \\
\hline Predicted probability & 0.22 & 0.25 & 0.01 & 0.52 \\
\hline
\end{tabular}

Note: Type I households: those who never participated; Type II households: Those who participated in 2007-08 but not in 2009-10; Type III households: Those who participated first time in 2009-10; Type IV households: Those who participated in both the years. ${ }^{* * *},{ }^{* *},{ }^{*}$ refer to significance at the $1 \%, 5 \%$ and $10 \%$ level, respectively; and $w$ denotes weakly significant (>10\% level). Figures in the parenthesis are the $z$-values. ME=Marginal Effect (dy/dx) 


\section{Figure 1: Venn-diagram for Participation Dynamics}

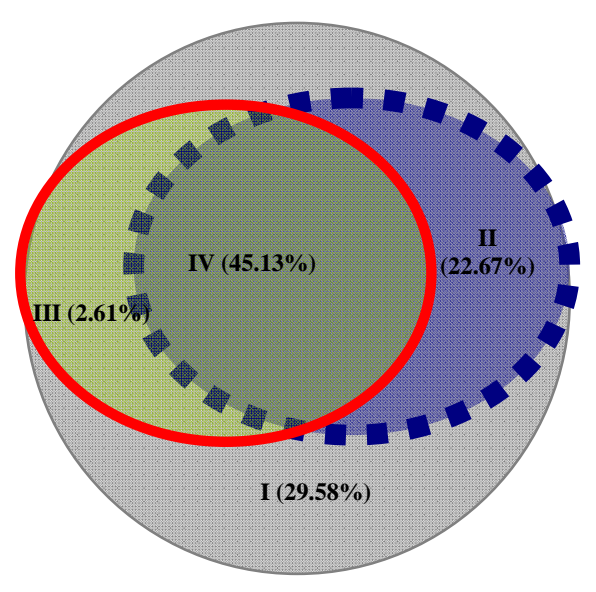

Please note that figures in the parenthesis are the percentage proportions of Type I, II, III and IV households among total population of panel households.

Figure 2: Cumulative Distribution Functions of Per Capita Monthly Consumption Expenditure (in INR) for Household who never Participated (Type I households): 2007-08 and 2009-10

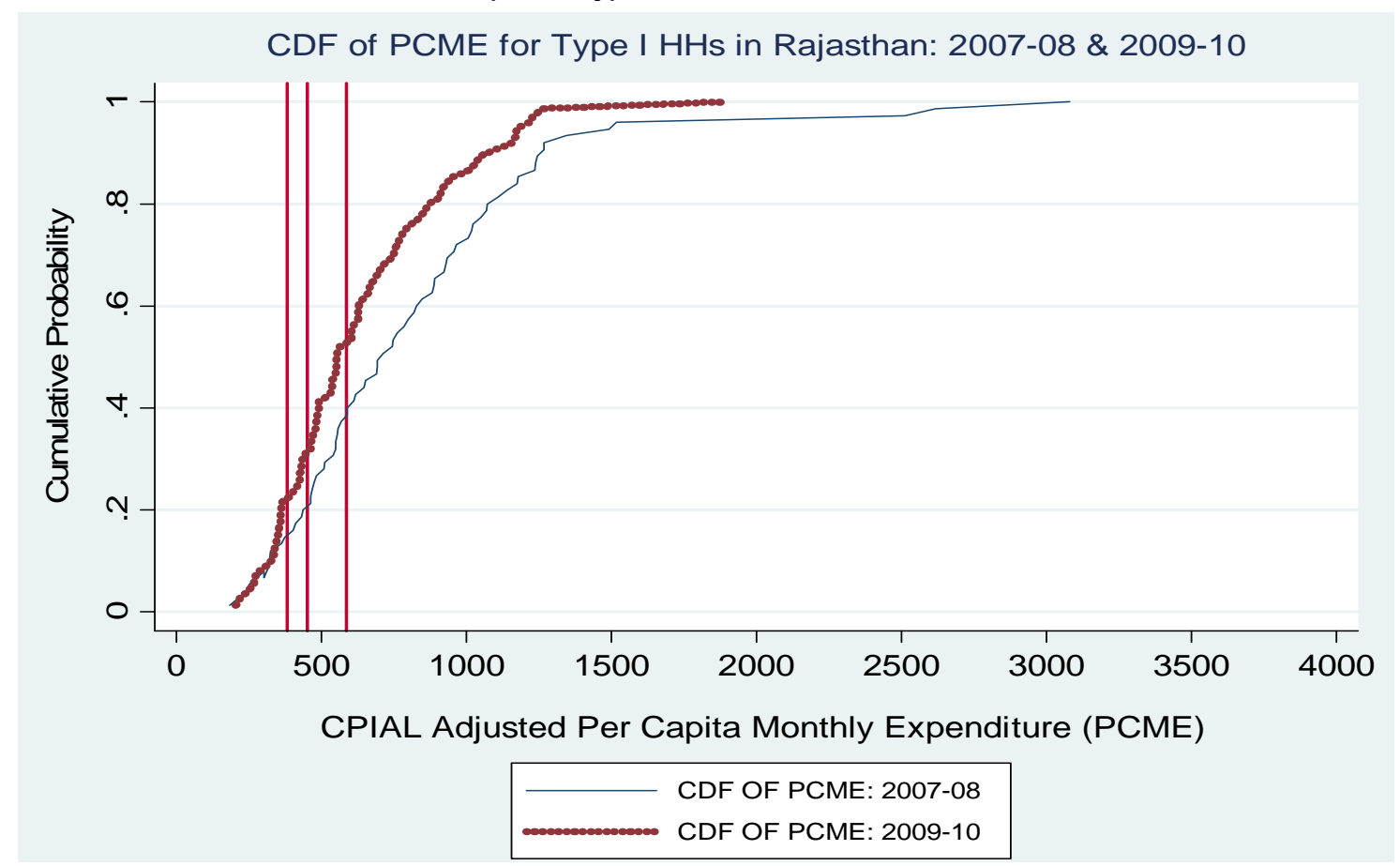

Note: vertical reference lines are drawn at 383, 450 (poverty cut-off) and 585, respectively 
Figure 3: Cumulative Distribution Functions of Per Capita Monthly Consumption Expenditure (in INR) for Households who Withdrew after initial Participation (Type II households): 2007-08 and 2009-10

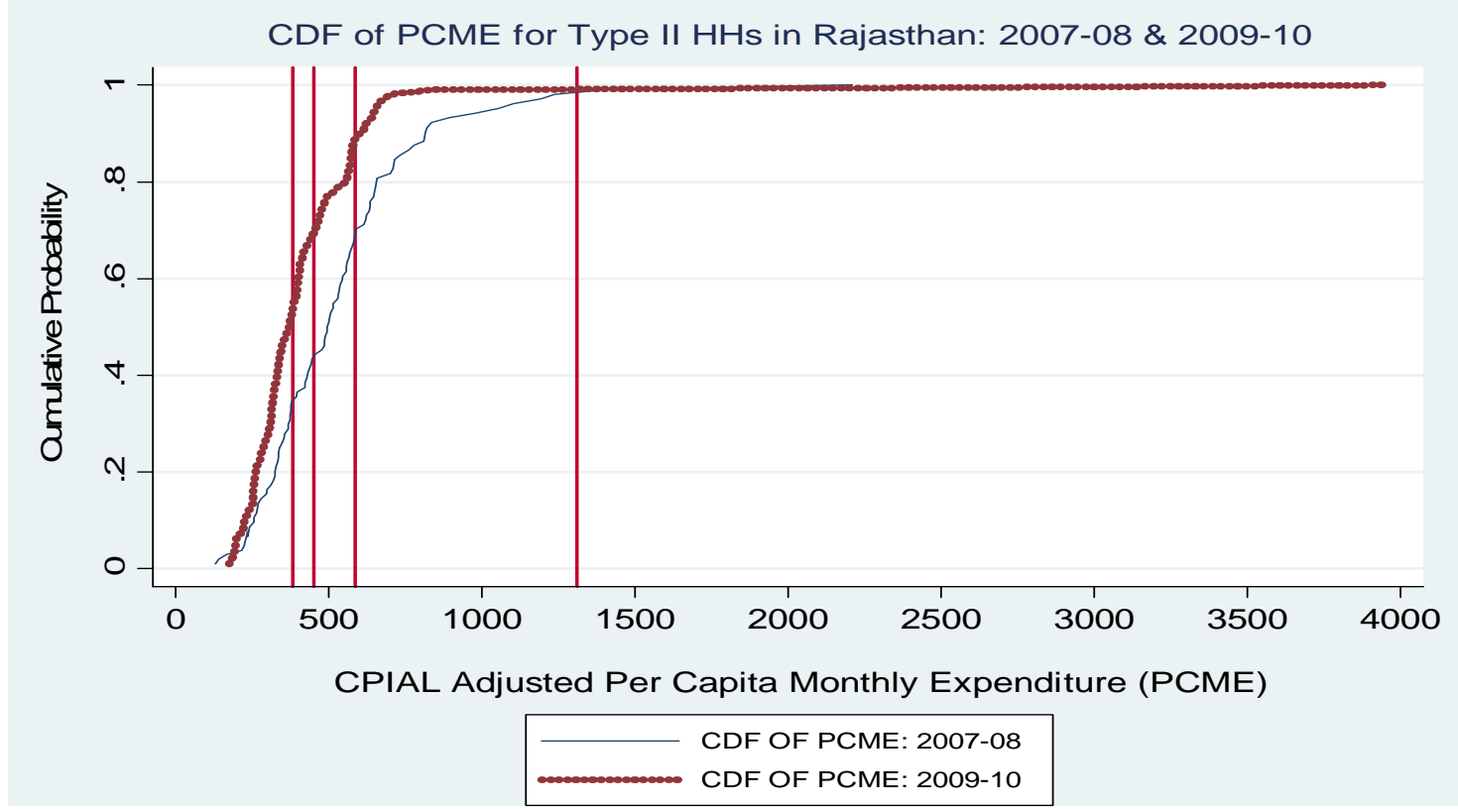

Note: vertical reference lines are drawn at 383, 450 (poverty cut-off), 585 and 1312, respectively

Figure 4: Cumulative Distribution Functions of Per Capita Monthly Consumption Expenditure (in INR) for Households who Participated First Time (Type III households): 2007-08 and 2009-10

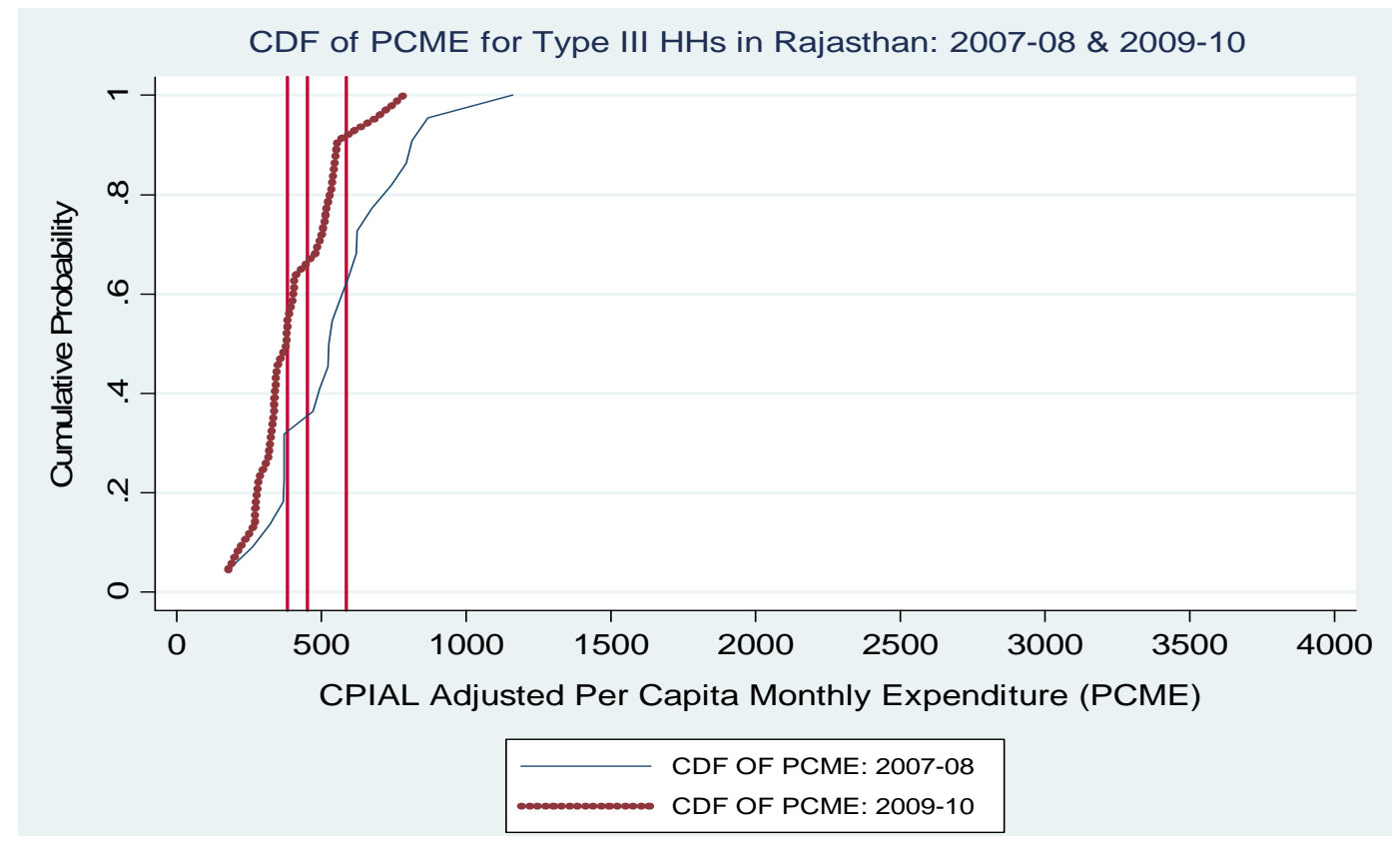

Note: vertical reference lines are drawn at 383, 450 (poverty cut-off), 585 and 1312, respectively 
Figure 5: Cumulative Distribution Functions of Per Capita Monthly Consumption Expenditure (in INR) for Household who Continued Participation (Type IV households): 2007-08 and 2009-10

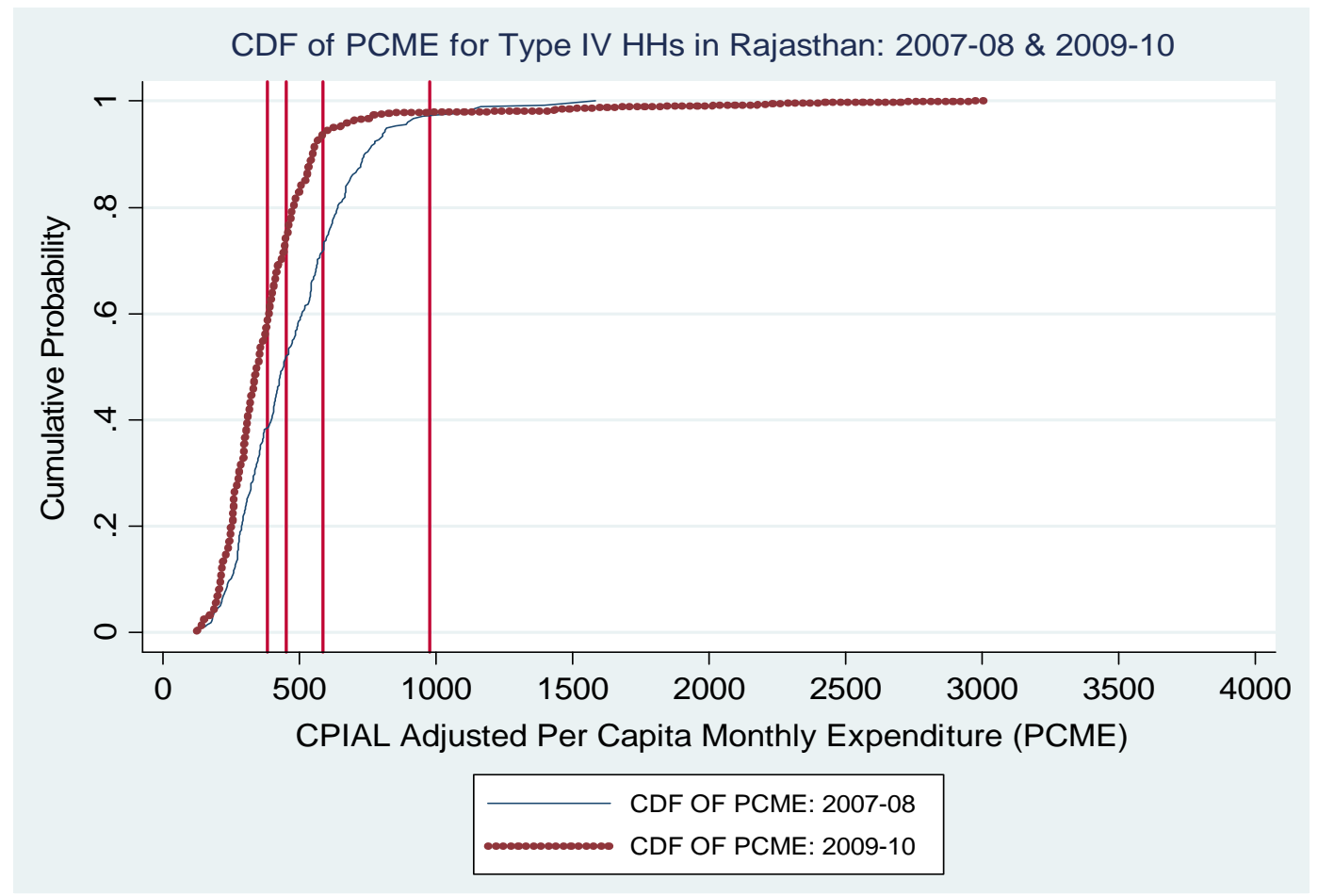

Note: vertical reference lines are drawn at 383, 450 (poverty cut-off), 585 and 976, respectively

Figure 6: Cumulative Distribution Functions of Per Capita Monthly Income Net of NREGS Earnings (in INR) for Household who Never Participated (Type I households): 2007-08 and 2009-10

CDF of PCMINNE for Type I HHs in Rajasthan: 2007-08 \& 2009-10

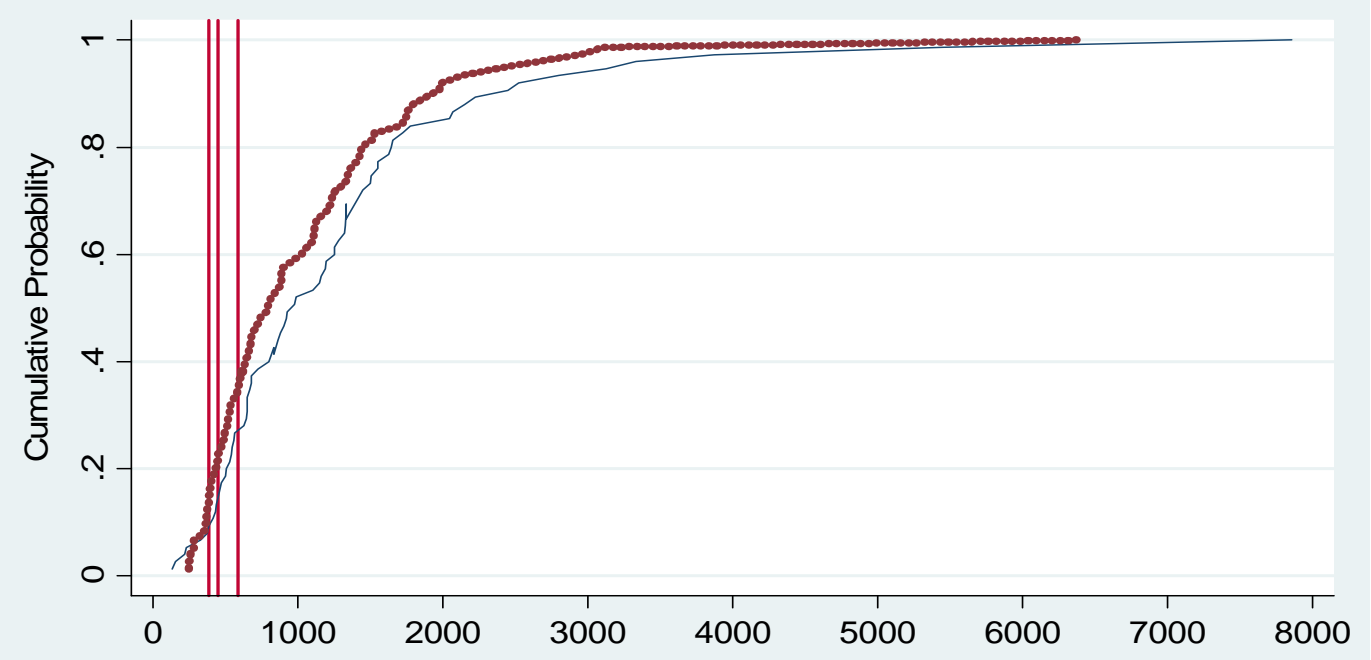

CPIAL Adjusted Per Capita Monthly Income Net of NREGS Earnings (PCMINNE)

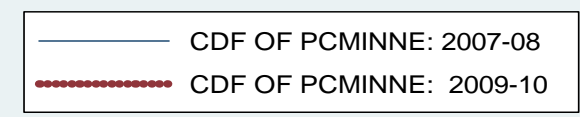

Note: vertical reference lines are drawn at 383, 450 (poverty cut-off) and 585, respectively 
Figure 7: Cumulative Distribution Functions of Per Capita Monthly Income Net of NREGS Earnings (in INR) for Households who Withdrew after initial Participation (Type II households): 2007-08 and 2009-10

CDF of PCMINNE for Type II HHs in Rajasthan: 2007-08 \& 2009-10

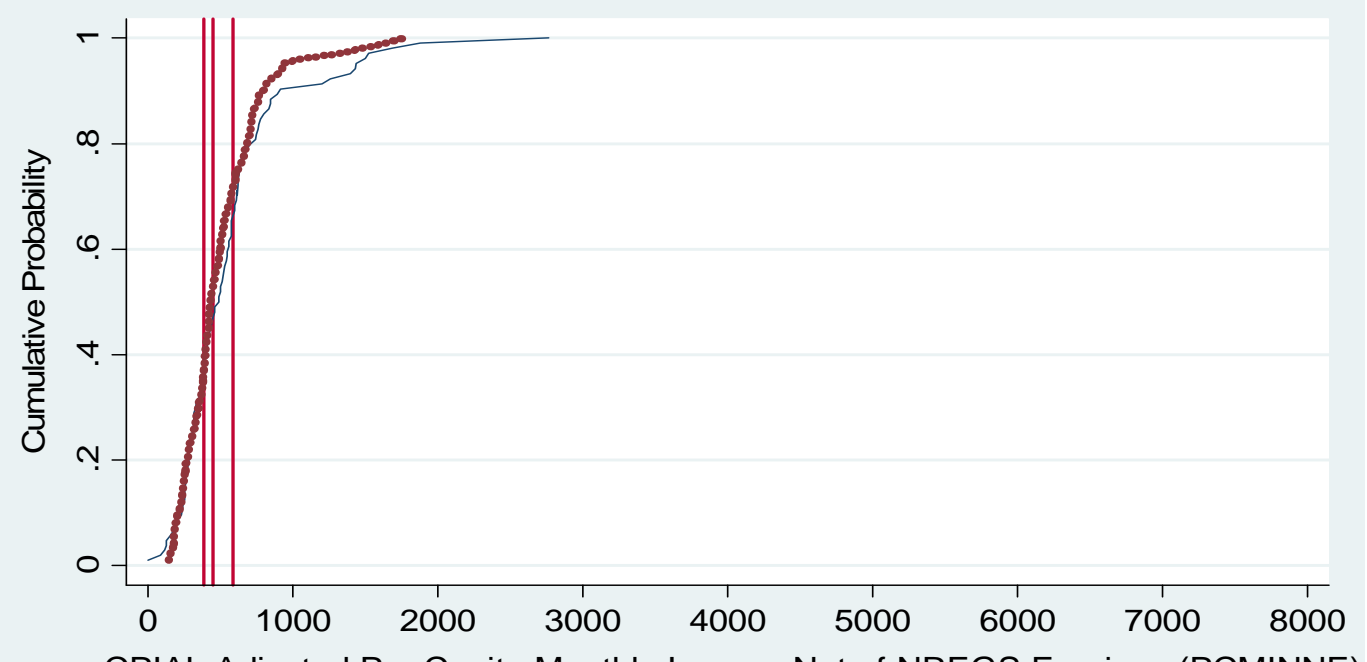

CPIAL Adjusted Per Capita Monthly Income Net of NREGS Earnings (PCMINNE)

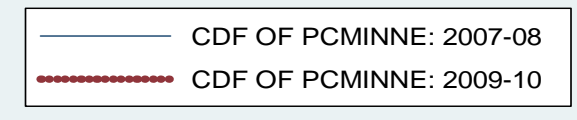

Note: vertical reference lines are drawn at 383, 450 (poverty cut-off) and 585, respectively

Figure 8: Cumulative Distribution Functions of Per Capita Monthly Income Net of NREGS Earnings (in INR) for Households who Participated First Time (Type III households): 2007-08 and 2009-10

CDF of PCMINNE for Type III HHs in Rajasthan: 2007-08 \& 2009-10

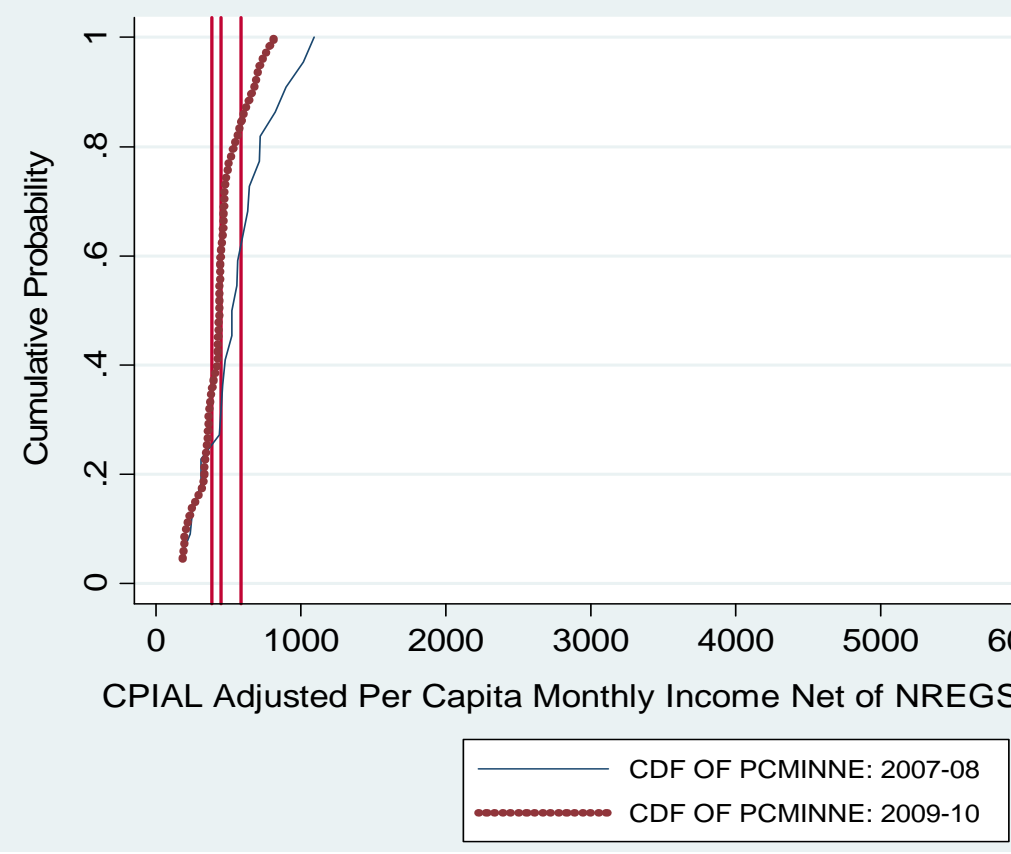

Note: vertical reference lines are drawn at 383, 450 (poverty cut-off) and 585, respectively 
Figure 9: Cumulative Distribution Functions of Per Capita Monthly Income Net of NREGS Earnings (in INR) for Household who Continued Participation (Type IV households): 2007-08 and 2009-10

CDF of PCMINNE for Type IV HHs in Rajasthan: 2007-08 \& 2009-10

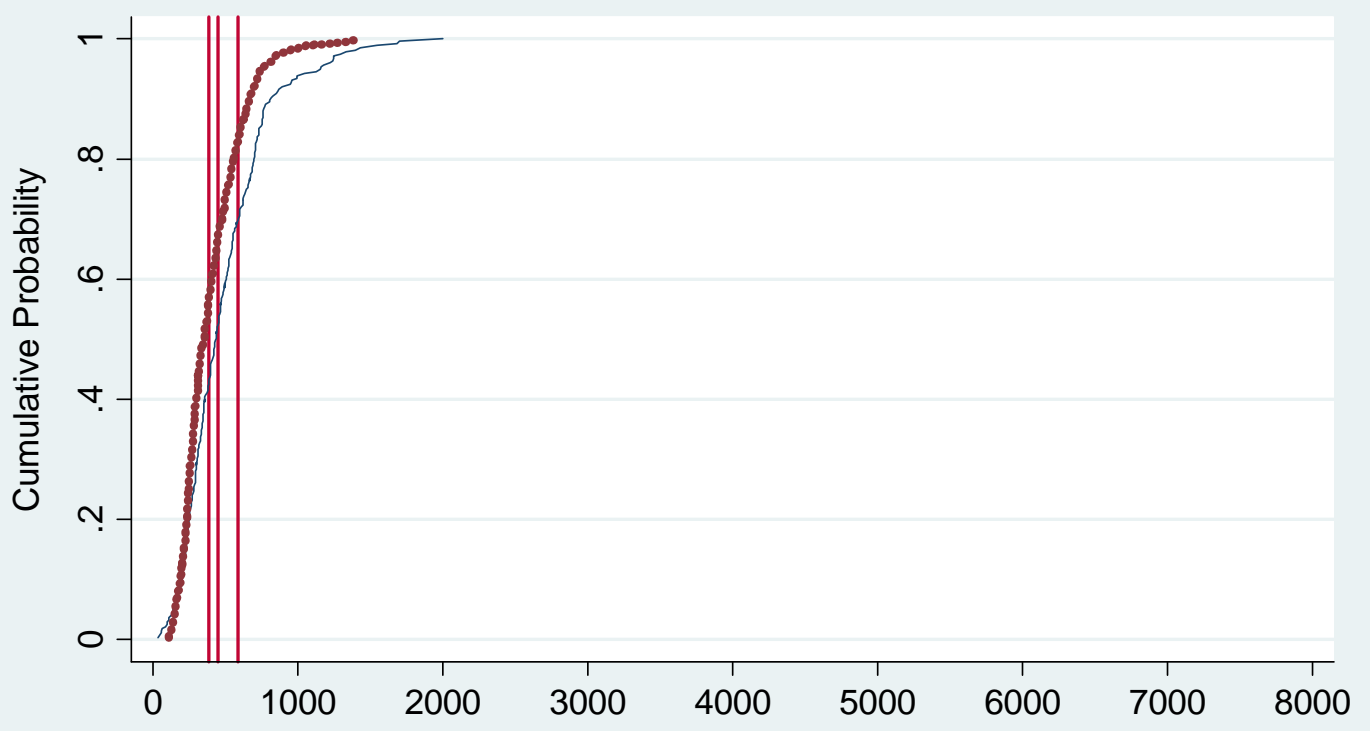

CPIAL Adjusted Per Capita Monthly Income Net of NREGS Earnings (PCMINNE)

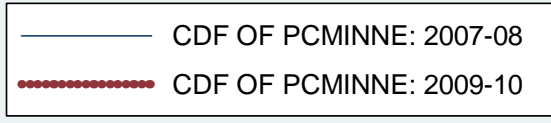

Note: vertical reference lines are drawn at 383, 450 (poverty cut-off) and 585, respectively 
APPENDIX

Table A.1: Definition of different levels of Poverty

\begin{tabular}{|l|c|}
\hline Household's poverty status & $\begin{array}{c}\text { CPIAL adjusted per capita monthly } \\
\text { consumption expenditure Ranges* }\end{array}$ \\
\hline Acute poverty & $<$ Rs. 383 \\
\hline Moderate poverty & $\geq$ Rs. 383 but $<$ Rs. 450 \\
\hline Moderate Non-poverty & $\geq$ Rs. 450 but $<$ Rs. 585 \\
\hline Affluent & $\geq$ Rs. 585 \\
\hline Non-poor & $\geq$ Rs. 450 \\
\hline Poor & $<$ Rs. 450 \\
\hline
\end{tabular}

*Please note that to adjust per capita monthly consumption expenditure using CPIAL we multiply per capita monthly consumption expenditure (and all other income variables) for 2009-10 by ratio of CPIAL in 2007-08 to CPIAL in 2009-10 (=0.797270955). 
Table A.2: Definitions of the Variables used in the Analysis

\begin{tabular}{|c|c|}
\hline Variables & Definition \\
\hline \multicolumn{2}{|l|}{ Dependent Variable } \\
\hline \%change in Per Capita Monthly Expenditure & $\begin{array}{l}=(\text { per capita monthly expenditure in } 2009-10 \text { minus per capita monthly expenditure in } \\
2007-08)^{*} 100 / \text { per capita monthly expenditure in } 2007-08\end{array}$ \\
\hline $\begin{array}{l}\text { \%change in Per Capita Monthly Income Net of } \\
\text { NREGS Earnings }\end{array}$ & $\begin{array}{l}=\text { (per capita monthly income net of nregs earnings in 2009-10 minus per capita } \\
\text { monthly income net of NREGS earnings in 2007-08)*100/per capita monthly income } \\
\text { net of NREGS earnings in 2007-08 }\end{array}$ \\
\hline Type of households: mlogit & $\begin{array}{l}\text { 1=Type I households (those who never participated in NREGS); } \\
2=\text { Type II households (those who participated in 2007-08 but withdrew in 2009-10); } \\
3=\text { Type III households (those who did not participate in 2007-08 } \\
\quad \text { but first time in 2009-10, and } \\
\begin{array}{l}4=\text { Type IV households (those who participated in 2007-08 and continued in 2009-10); } \\
1 \text { is the reference category }\end{array}\end{array}$ \\
\hline \multicolumn{2}{|l|}{ Explanatory Variables } \\
\hline Type I households: Dummy (Reference) & $=1$ if a household neither participated in 2007-08 nor in 2009-10; 0 otherwise \\
\hline Type II households: Dummy & $=1$ if a household participated in 2007-08 but not in 2009-10; 0 otherwise \\
\hline Type III households: Dummy & $=1$ if a household not participated in $2007-08$ but in $2009-10 ; 0$ otherwise \\
\hline Type IV households: Dummy & $=1$ if a household participated in both $2007-08$ and in $2009-10 ; 0$ otherwise \\
\hline Social group dummy: SC & $=1$ if social group is Scheduled Castes, 0 otherwise \\
\hline Social group dummy: ST & $=1$ if social group is Scheduled Tribes, 0 otherwise \\
\hline Social group dummy: OBC & $=1$ if social group is $\mathrm{OBC}, 0$ otherwise \\
\hline Social group dummy: Others (Reference) & Omitted social group \\
\hline Household Size: 2007-08 & Household size in base year $2007-08$ \\
\hline $\begin{array}{l}\text { Change in household size: } \\
2007-08 \text { and } 2009-10\end{array}$ & $\begin{array}{l}\text { Change in household size during } 2007-08 \text { and } 2009-10 \\
\text { (household size in 2009-10 minus household size in base year 2007-08) }\end{array}$ \\
\hline$\%$ adults in the household: $2007-08$ & $\begin{array}{l}\text { \% of adults in the total household size in base year } 2007-08 \\
\text { (=number of total adults in the household } 100 / \text { household size) }\end{array}$ \\
\hline$\Delta \%$ adult in the household: $2007-08$ to $2009-10$ & $\begin{array}{l}\text { change in the share of adults in the household during } 2007-08 \text { and } 2009-10 \\
(\% \text { in 2009-10 minus 2007-08) }\end{array}$ \\
\hline Per capita monthly expenditure: $2007-08$ & Per capita monthly expenditure in base year 2007-08 \\
\hline $\begin{array}{l}\text { Per capita monthly income net of NREGS } \\
\text { earnings: } 2007-08\end{array}$ & Per capita monthly income net of NREGS Earnings in base 2007-08 \\
\hline Land owned by household: 2007-08 & Land owned by household in 2007-08 (in acres) \\
\hline $\begin{array}{l}\Delta \text { Land owned by household: } 2007-08 \text { to } 2009- \\
10\end{array}$ & $\begin{array}{l}\text { Change in land owned by household during 2007-08 and 2009-10 } \\
\text { (=land owned in 2009-10 minus 2007-08) }\end{array}$ \\
\hline $\begin{array}{l}\text { Ratio of NREG to AGR wage rate in village: } \\
2007-08\end{array}$ & Ratio of NREG wage to agricultural wage rate at the village level in 2007-08 \\
\hline $\begin{array}{l}\triangle \text { Ratio of NREG to AGR wage rate in village: } \\
2007-08 \text { to } 2009-10\end{array}$ & $\begin{array}{l}\text { Change in ratio of NREG wage to agricultural wage rate at the village level } \\
\text { during 2007-08 and 2009-10 (ratio in 2009-10 minus ratio in 2007-08) }\end{array}$ \\
\hline $\begin{array}{l}\text { Average distance of NREG Sites from the } \\
\text { village: } 2007-08\end{array}$ & Average distance of NREG sites from the village in 2007-08 \\
\hline $\begin{array}{l}\text { Per capita annual earnings from } \\
\text { non-agricultural sources net of NREGS } \\
\text { earnings in village: } 2007-08\end{array}$ & $\begin{array}{l}\text { Village level per capita annual earnings from non-agricultural sources net of NREGS } \\
\text { earnings in 2007-08 }\end{array}$ \\
\hline $\begin{array}{l}\triangle \text { Per capita annual earnings from non- } \\
\text { agricultural sources net of NREGS earnings in } \\
\text { village: } 2007-08 \text { to } 2009-10\end{array}$ & $\begin{array}{l}\text { Relative change in per capita annual earnings from non-agricultural sources net of } \\
\text { NREGS earnings in village during 2007-08 to 2009-10 }\end{array}$ \\
\hline
\end{tabular}

